\title{
Long-term patterns in dissolved organic carbon, major elements and trace metals in boreal headwater catchments: trends, mechanisms and heterogeneity
}

\author{
S. K. Oni ${ }^{1}$, M. N. Futter ${ }^{1}$, K. Bishop ${ }^{1,2}$, S. J. Köhler ${ }^{1}$, M. Ottosson-Löfvenius ${ }^{3}$, and H. Laudon ${ }^{3}$ \\ ${ }^{1}$ Department of Aquatic Sciences and Assessment, Swedish University of Agricultural Sciences, Box 7050, 750 07, Uppsala, \\ Sweden \\ ${ }^{2}$ Department of Earth Sciences, Uppsala University, Villavägen 16, 752 36, Uppsala, Sweden \\ ${ }^{3}$ Department of Forest Ecology and Management, Swedish University of Agricultural Sciences, 901 83, Umeå, Sweden
}

Correspondence to: S. K. Oni (stephen.oni@slu.se)

Received: 15 November 2012 - Published in Biogeosciences Discuss.: 21 December 2012

Revised: 12 March 2013 - Accepted: 18 March 2013 - Published: 8 April 2013

\begin{abstract}
The boreal landscape is a complex, spatiotemporally varying mosaic of forest and mire landscape elements that control surface water hydrology and chemistry. Here, we assess long-term water quality time series from three nested headwater streams draining upland forest $(\mathrm{C} 2)$, peat/mire (C4) and mixed (C7) (forest and mire) catchments. Acid deposition in this region is low and is further declining. Temporal trends in weather and runoff (1981-2008), dissolved organic carbon concentration [DOC] (1993-2010) and other water quality parameters (1987-2011) were assessed. There was no significant annual trend in precipitation or runoff. However, runoff increased in March and declined in May. This suggested an earlier snowmelt regime in recent years. Significant monotonic increasing trends in air temperature and length of growing season suggested a decrease in snowfall and less spring runoff. Stream [DOC] was positively correlated with some trace metals (copper, iron and zinc) and negatively with several other chemical parameters (e.g. sulfate, conductivity, calcium). Both sulfate and conductivity showed declining trends, while a significant increase was observed in $\mathrm{pH}$ during winter and spring. Calcium and magnesium showed monotonic decreasing trends. The declining trajectories of stream base cation and sulfate concentrations during other times of the year were not accompanied by changes in $\mathrm{pH}$ and alkalinity. These results indicate subtle effects of recovery from acidification. Water temperature increased significantly both annually and in most months. A simultaneous monotonic increase in iron $(\mathrm{Fe})$ and $[\mathrm{DOC}]$
\end{abstract}

in autumn suggests co-transport of Fe-DOC in the form of organometallic complexes. A monotonic increase in UV absorbance in most months without co-occurring changes in DOC trend suggests a shift in DOC quality to a more humicrich type. The observed increase in soil solution [DOC] and subtle trends in stream [DOC] suggest that climate rather than recovery from acidification is the dominant driver of DOC trends in the Svartberget catchment.

\section{Introduction}

Understanding seasonal and long-term trends in dissolved organic matter is needed to explain nutrient, carbon, trace metal and base cation cycling in boreal forest ecosystems (e.g. Berggren et al., 2009; Schindler et al., 1997). Dissolved organic carbon (DOC), the fraction of natural organic matter able to pass through a $0.45 \mu \mathrm{m}$ filter, is a heterogeneous mixture of complex-structured organic compounds of various terrestrial and in-stream origins (Kalbitz et al., 2000; Selberg et al., 2011).

In recent years, several studies have reported increasing trends in DOC concentration ([DOC]) in surface waters in different parts of the northern hemisphere (Evans et al., 2005; Erlandsson et al., 2008; Monteith et al., 2007). Several factors (or combinations of factors) have been recognized as drivers of the observed trends in $[\mathrm{DOC}]$ in streams and lakes. However, regional differences, effects of scale and 
local processes have not allowed a unified consensus to be reached (Clark et al., 2010). In the United Kingdom, for example, sea salt, declines in acid deposition (Dawson et al., 2009; Evans et al., 2006: Monteith et al., 2007), nitrogen enrichment (Worrall et al., 2004) and elevated atmospheric $\mathrm{CO}_{2}$ (Fenner et al., 2007; Freeman et al., 2004) have all been recognized as possible drivers of trends. In North America, changes in precipitation and runoff regimes (Eimers et al., 2008), acid deposition and nitrogen enrichment (Findlay, 2005) as well as weather variability (Striegl et al., 2005) have also been noted amongst some other factors. In Scandinavia, changes in acid deposition (de Wit et al., 2007), changes in weather and/or runoff regimes (Hongve et al., 2004; Lepistö et al., 2008), or a combination of the two (Erlandsson et al., 2008) have been identified as the drivers of observed [DOC] trends in streams and lakes. This conclusion has been supported by modelling studies (Futter et al., 2009, 2011). Other factors reported as drivers of DOC in the literature include drought (Worrall and Burt, 2005), landscape disturbance such as land use change (Aitkenhead-Peterson et al., 2009), forest clear cutting (Schelker et al., 2012) and climate change (Oni et al., 2012; Schindler et al., 1997).

These widely reported increases have implications for overall catchment carbon budgets and water quality, as DOC is a master variable controlling the chemistry of boreal surface waters. Because DOC can bind protons and modify the redox properties of other organic ligands, both the chemical and physical properties of some other key water quality parameters will be affected. Changes in production or transport of DOC will modify the mobility, toxicity, speciation and bioavailability of elements such as mercury (Ravichandran, 2004), silica (e.g. Klaminder et al., 2011a), copper (Brooks et al., 2007; Shank et al., 2004), lead (Klaminder et al., 2006) and cesium (Tegen and Dorr, 1996) as well as persistent organic pollutants (e.g. Bergknut et al., 2011). In addition, DOC cycling strongly influences base cation dynamics and exports in forest ecosystems (Raulund-Rasmussen et al., 1998). Increases in DOC following recovery from acidification can also influence base cation exports and as a result control the buffering capacity of soils and surface waters (Evans et al., 2005). Evaluation of recovery from acidification is therefore important in boreal systems as the associated changes in stream chemistry can have large impacts on overall aquatic ecosystem health.

Headwaters exert an important control on the overall carbon budget and water quality status of catchments but there is a lack of understanding of headwater biogeochemical processes since most monitoring efforts are focused on higher order streams or downstream of larger catchments (Oni et al., 2011; Temnerud and Bishop, 2005). This has been described as "Aqua Incognita" by Bishop et al. (2008). Large river basins will contain a mixture of DOC of different quality from various landscape sources making the DOC dynamics more uniform over time and space (Oni et al., 2013). In contrast, the DOC processes in headwaters are depen- dent on both local soil conditions and hydrology that both have a heterogeneous nature. As a result, headwater [DOC] can be highly variable (Temnerud et al., 2010; Buffam et al., 2008). While relating downstream chemical parameters to upstream areas may provide useful understanding about headwater biogeochemistry, studying the smallest units of the landscape mosaic such as wetland and upland forest landscape units is important to understand the processes driving the long- term water quality trends in boreal catchments.

Climate variables control both the in-soil and in-stream carbon processes and increases in temperature can increase the rate of both biological and chemical processes (Futter et al., 2007; Köhler et al., 2008, 2009). Land use and hydrology also influence DOC quality and quantity. The DOC from forest dominated catchments can be more labile and bioavailable for microbial degradation or utilisation in the aquatic food web (Berggren et al., 2009). DOC originating from wetlands is often less susceptible to degradation (Ågren et al., 2008; Berggren et al., 2007). Biotic processes such as microbial production and mineralisation (Berggren et al., 2009) are important second order controls on surface water [DOC]. There can be both positive and negative discharge/[DOC] relationships in boreal headwaters, depending on whether the stream drains a forest or mire landscape element. Hydrological mobilization from organic rich soils adjacent to streams is an important control on DOC dynamics in forest dominated boreal catchments (Winterdahl et al., 2011a). The riparian soil-stream interface is important for DOC production in boreal forest catchment due to the strong hydrological connectivity between soils, groundwater and surface waters (Bishop et al., 1994; Laudon et al., 2011). Riparian zones are characterized by wetter conditions than upland parts of a catchment (McGlynn and McDonnell, 2003) and can react rapidly to changing groundwater levels (Bishop et al., 2004). As a result, the riparian zone can contribute more to stream DOC during the rising limb of runoff hydrograph than the corresponding falling limb (McGlynn and McDonnell, 2003). However, forest and mire landscape elements can display markedly different seasonal responses (Bishop and Pettersson, 1996; Köhler et al., 2008, Eimers et al., 2008; Laudon et al., 2004a, 2011).

Differences in environmental factors including climate influence catchment water retention and residence time in boreal ecosystems. Due to heterogeneity in the landscape, small scale effects controlling DOC production and mobilization at plot scales are not apparent at catchment scale. Complex interactions exist amongst landscape and stream biogeochemical mechanisms, as relationships between surface water chemical parameters are not always linear. Therefore, long-term data are valuable to identify major drivers of trends in water quality and are a complement to seasonal trend and/or other short-term process based studies.

The objectives of this study were (1) to evaluate the temporal pattern of long-term and seasonal trends in stream chemical parameters and surface water [DOC] in three contrasting 


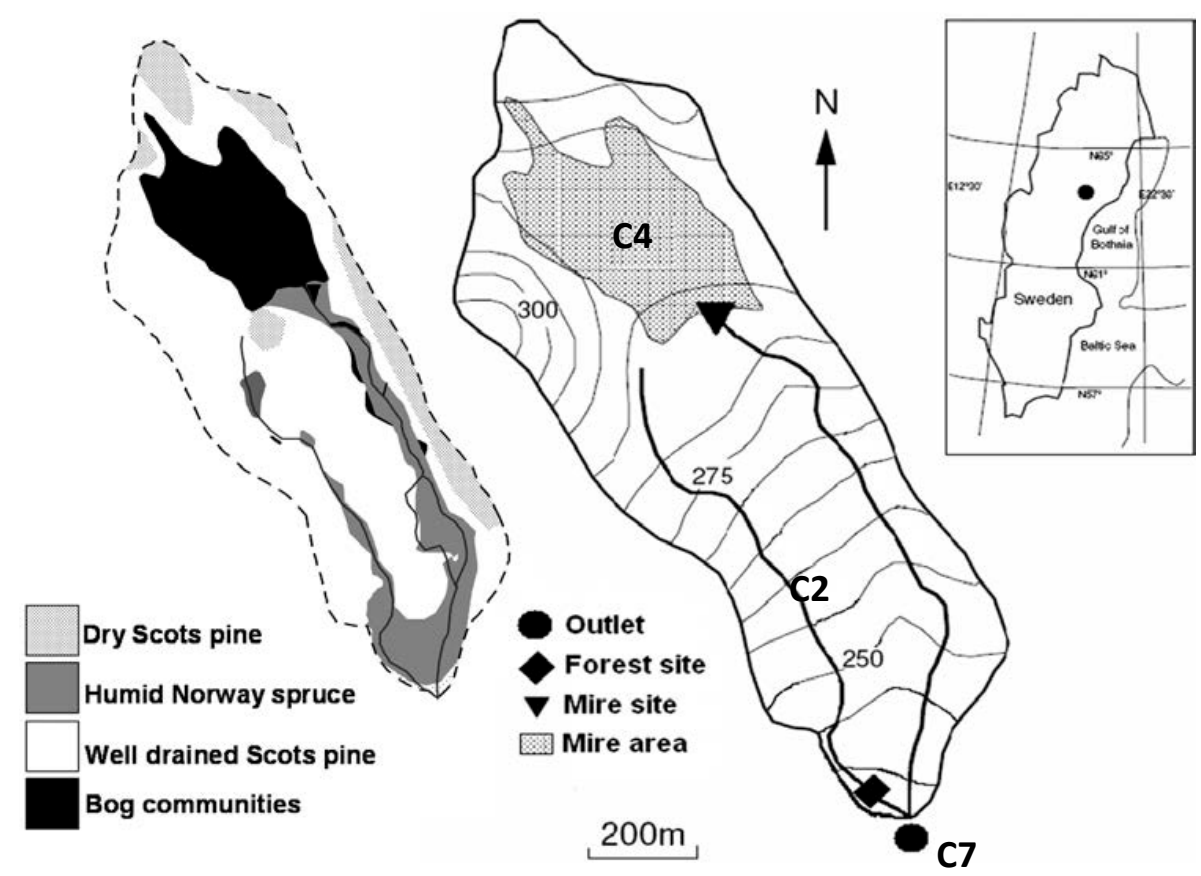

Fig. 1. Map of Svartberget catchment.

headwater streams draining forest, mire and a mixture of both landscape elements; (2) to identify the driver(s) of trends and plausible linkages between DOC dynamics and mechanisms controlling the cycling of other carbon dependent parameters such as trace metals, base cations, etc. in a small boreal catchment; and (3) to evaluate riparian controls on stream [DOC] in a headwater boreal catchment. The monitored parameters include both deposition and stream chemistry. Chemical monitoring includes [DOC] and other representative in-stream chemical parameters (absorbance, $\mathrm{pH}$, chloride, conductivity, alkalinity and sulfate), trace metals (iron, copper, zinc and silicon) and base cations (calcium, magnesium, potassium and sodium). Several studies report on parts of this record (Grip and Bishop, 1990; Köhler et al., 2008; Winterdahl et al., 2011a; Yurova et al., 2008) but none has examined the entire $25+$ yr record for some parameters and their possible linkages with DOC dynamics. It is our expectation that this study will contribute to the understanding of the dominant biogeochemical mechanisms and lead to improved process-modelling efforts in pristine boreal headwater catchments in the future.

\section{Methods}

\subsection{Site descriptions and stream monitoring}

This study was conducted in the Svartberget catchment $\left(64^{\circ} 14^{\prime} \mathrm{N}, 10^{\circ} 46^{\prime} \mathrm{E}\right)$ located about $60 \mathrm{~km}$ northwest of Umeå in Northern Sweden (Fig. 1). Svartberget is an unmanaged 50 ha boreal catchment, centrally located within the Kryck- lan study catchment. Streams in the catchment were ditched in the late 19th and early 20th centuries to improve drainage (Esseen et al., 1997). The catchment receives limited deposition of sulfate $\left(\sim 2 \mathrm{~kg} \mathrm{ha}^{-1} \mathrm{SO}_{4}-\mathrm{S} \mathrm{yr}^{-1}\right)$ and inorganic nitrogen $\left(<2 \mathrm{~kg} \mathrm{ha}^{-1} \mathrm{~N} \mathrm{yr}^{-1}\right)$. As a result, Svartberget is probably only slightly acidified. However, episodic acidification of streams has been observed in the region (Bishop et al., 2000; Laudon and Bishop, 2002). The catchment consists of two headwater streams draining contrasting landscape elements of forest and mire, which dominate the boreal landscape (Fig. 1). Forests in the catchment comprise approximately century old Norway spruce (Picea abies) and Scots pine (Pinus sylvestris) (Laudon et al., 1999). Vegetation in the mires mainly consists of Sphagnum sp. (Yurova et al., 2008). The region has a long-term mean air temperature of $1.7^{\circ} \mathrm{C}(1981-2008)$ with the highest temperatures occurring in July. Total annual precipitation in the catchment averages $610 \pm 109 \mathrm{~mm} \mathrm{yr}^{-1}$, of which $35-50 \%$ falls as snow (Köhler et al., 2008). The spring snowmelt is the dominant hydrologic event and lasts for about six weeks (Buffam et al., 2007). On average the snow cover in the catchment lasts $\sim 170$ days from October to May (Köhler et al., 2008; Laudon et al., 2011; Löfvenius et al., 2003). Annual runoff is $320 \pm 97 \mathrm{~mm} \mathrm{yr}^{-1}$ with subsurface pathways dominating the delivery of runoff especially in forest-dominated landscape elements (Laudon et al., 2007).

The geology of the catchment consists of gneissic bedrock overlain by till of varying thickness (Bishop et al., 2000; Buffam et al., 2007). The presence of well-developed ironpodzol soils enhances the formation of organic soils in 
Table 1. The significance of monthly and overall Mann-Kendall trend statistics for climate, runoff, stream [DOC], in-stream chemical parameters, base cations as well as trace metals in Svartberget catchment. Except for stream [DOC] that were available in the three headwater streams (C2, C4 and C7), other chemical parameters (and runoff) were available from C7. The values in italics represent statistically significant declines and the values in bold represent statistically significant monotonic increasing trends.

\begin{tabular}{|c|c|c|c|c|c|c|c|c|c|c|c|c|c|c|c|c|c|}
\hline \multirow{3}{*}{\multicolumn{2}{|c|}{ Group }} & \multirow[b]{3}{*}{ Parameter } & \multirow[b]{3}{*}{$\begin{array}{l}\text { Data } \\
\text { Period }\end{array}$} & \multirow[b]{3}{*}{ Mean } & \multicolumn{13}{|c|}{ Mann-Kendall trend (MKT) statistics } \\
\hline & & & & & \multicolumn{12}{|c|}{ Monthly } & \multirow[b]{2}{*}{ Overall } \\
\hline & & & & & Jan & $\mathrm{Feb}$ & Mar & Apr & May & Jun & Jul & Aug & Sep & Oct & Nov & Dec & \\
\hline \multirow{4}{*}{ 苑 } & \multirow{4}{*}{ 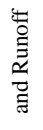 } & Precipitation $\left(\mathrm{mm} \mathrm{yr}^{-1}\right)$ & $1981-2008$ & 610 & & & & & & & & & & 0.066 & & & \\
\hline & & Air temperature $\left({ }^{\circ} \mathrm{C}\right)$ & $1981-2008$ & 1.7 & 0.039 & & & 0.039 & & & & 0.008 & 0.044 & & & 0.011 & $<0.01$ \\
\hline & & Runoff $\left(\mathrm{mm} \mathrm{yr}^{-1}\right)$ & $1981-2008$ & 320 & & & 0.039 & & 0.069 & & & & & 0.082 & & & \\
\hline & & Water Temperature $\left({ }^{\circ} \mathrm{C}\right)$ & $1987-2011$ & 3.5 & 0.062 & & 0.058 & 0.006 & 0.000 & $\mathbf{0 . 0 3 1}$ & 0.000 & 0.001 & 0.002 & & & & $<0.01$ \\
\hline \multirow{9}{*}{ 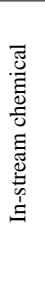 } & \multirow{9}{*}{ 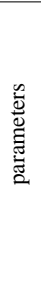 } & Absorbance (nm) & $1987-2011$ & 0.473 & $\mathbf{0 . 0 3 3}$ & 0.047 & & 0.019 & 0.005 & & & 0.002 & & 0.033 & 0.033 & 0.033 & $<0.01$ \\
\hline & & $\mathrm{pH}$ & $1987-2011$ & 5.2 & 0.048 & & 0.091 & & 0.002 & 0.036 & & & & & & & \\
\hline & & Alkalinity $\left(\mathrm{mg} \mathrm{L}^{-1}\right)$ & $1987-2011$ & -0.310 & & & & 0.005 & 0.040 & & & 0.036 & 0.012 & 0.024 & 0.009 & 0.056 & 0.010 \\
\hline & & $\mathrm{SO}_{4}-\mathrm{S}\left(\mathrm{mg} \mathrm{L}^{-1}\right)$ & $1987-2011$ & 5.297 & 0.008 & 0.004 & 0.001 & 0.000 & 0.002 & & 0.017 & 0.002 & 0.044 & 0.024 & 0.027 & 0.015 & $<0.01$ \\
\hline & & Chloride $\left(\mathrm{mg} \mathrm{L}^{-1}\right)$ & $1987-2011$ & 0.832 & & & 0.010 & 0.022 & & & & & & & 0.094 & 0.098 & \\
\hline & & Conductivity (mS) & $1987-2011$ & 3.262 & 0.021 & 0.017 & 0.003 & 0.006 & 0.003 & 0.008 & 0.047 & 0.035 & 0.004 & 0.007 & 0.005 & & $<0.01$ \\
\hline & & $\mathrm{C} 2[\mathrm{DOC}]\left(\mathrm{mg} \mathrm{L}^{-1}\right)$ & $1993-2010$ & 15.14 & & & & 0.099 & & & & 0.072 & 0.054 & 0.099 & 0.009 & & $<0.01$ \\
\hline & & $\mathrm{C} 4[\mathrm{DOC}]\left(\mathrm{mg} \mathrm{L}^{-1}\right)$ & $1993-2010$ & 31.00 & & & & & & & & 0.034 & 0.007 & 0.059 & & & \\
\hline & & $\mathrm{C} 7[\mathrm{DOC}]\left(\mathrm{mg} \mathrm{L}^{-1}\right)$ & $1993-2010$ & 20.81 & & & & & & & & 0.017 & 0.014 & 0.011 & & & \\
\hline \multirow{4}{*}{$\begin{array}{l}\ddot{\tilde{F}} \\
\tilde{\tilde{F}} \\
\tilde{D}\end{array}$} & \multirow{4}{*}{ 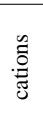 } & $\mathrm{Ca}\left(\mathrm{mg} \mathrm{L}^{-1}\right)$ & 1987-2011 & 2.317 & 0.023 & 0.033 & 0.005 & 0.017 & 0.039 & & 0.025 & 0.064 & 0.029 & & 0.035 & 0.042 & $<0.01$ \\
\hline & & $\operatorname{Mg}\left(\mathrm{mg} \mathrm{L}^{-1}\right)$ & $1987-2011$ & 0.772 & 0.035 & 0.059 & 0.056 & 0.026 & & & & 0.034 & & & & 0.067 & $<0.01$ \\
\hline & & $\mathrm{Na}\left(\mathrm{mg} \mathrm{L}^{-1}\right)$ & $1987-2011$ & 1.669 & & & & & & 0.016 & & & & & & & \\
\hline & & $\mathrm{K}\left(\mathrm{mg} \mathrm{L}^{-1}\right)$ & $1987-2011$ & 0.431 & & & 0.018 & 0.034 & 0.003 & & & & & & & & \\
\hline \multirow{4}{*}{$\stackrel{\mathscr{E}}{\mathbb{E}}$} & \multirow{4}{*}{$\begin{array}{l}\frac{n}{\tilde{\Xi}} \\
\Xi \\
\Xi\end{array}$} & $\mathrm{Si}\left(\mathrm{mg} \mathrm{L}^{-1}\right)$ & 1987-2011 & 4.774 & & 0.096 & & 0.053 & & & & & & & & 0.077 & \\
\hline & & $\mathrm{Fe}\left(\mathrm{mg} \mathrm{L}^{-1}\right)$ & $1987-2011$ & 1.240 & & & & & & & & $\mathbf{0 . 0 3 0}$ & 0.051 & 0.032 & 0.002 & 0.039 & 0.03 \\
\hline & & $\mathrm{Cu}\left(\mathrm{mg} \mathrm{L}^{-1}\right)$ & $1987-2011$ & 0.736 & 0.096 & & 0.004 & & & 0.041 & 0.000 & & 0.023 & & 0.086 & & $<0.01$ \\
\hline & & $\mathrm{Zn}\left(\mathrm{mg} \mathrm{L}^{-1}\right)$ & $1987-2011$ & 3.013 & & 0.076 & 0.019 & & 0.002 & 0.062 & & & & & 0.037 & & $<0.01$ \\
\hline
\end{tabular}

the forest-dominated part of the catchment. These soils are mostly located in riparian areas in close proximity to streams ( $\sim 50 \mathrm{~cm}$ depth). Shallower organic soils $(\sim 5 \mathrm{~cm})$ are also found in upland areas (Blomberg, 2009; Köhler et al., 2009). In the wetland part of the catchment the organic soil depth is on average $3-4 \mathrm{~m}$ but extends to $7 \mathrm{~m}$ in some places. The catchment elevation ranges from $235-310 \mathrm{~m}$ a.s.1. The catchment was delineated using a combination of digital elevation model (DEM) and light detection and ranging (LIDAR) into three subcatchments (Laudon et al., 2011). These comprise the forest dominated Västrabäcken (C2), mire dominated Kallkälsmyren (C4) and mixed Kallkälsbacken (C7) draining both mire and forest landscape elements. These subcatchments will be referred to as C2, C4 and C7 throughout this study (Fig. 1).

\subsection{Data collection}

In this study, we used long-term monitoring data from the Svartberget catchment which is the most intensively monitored part of the Krycklan Catchment Study (KCS), a nested set of boreal catchments in Northern Sweden. The availability of long-term time series provided an opportunity to test for trends in climate, deposition chemistry and water quality related parameters in the catchment both on long-term (annual) and seasonal time scales. Long-term measurements of atmospheric deposition of sulfate (1990-2007), chloride (1990-2007), dissolved inorganic nitrogen (1990-2006) and base cations (1990-2007) were used in evaluating the temporal trends of deposition in the catchment. Dissolved inorganic nitrogen (DIN) was estimated as the sum of nitrate $\left(\mathrm{N}-\mathrm{NO}_{3}\right)$ and ammonia $\left(\mathrm{N}-\mathrm{NH}_{4}\right)$ deposition.

Continuous daily time series of stream flow, air temperature and precipitation were available. Some $27 \mathrm{yr}$ of air temperature and precipitation data (1981-2008) were used in estimating seasonal and long-term trends as well as water temperature from 1987-2011 (Table 1). Streamflow was measured with a V-notch weir located in a heated dam house at the outlet of the catchment in C7.

Discrete water quality data from grab samples taken at approximately biweekly intervals in the $\mathrm{C} 7$ stream were also available. Twenty-four years (1987-2011) of trace metals, base cations and other in-stream chemical parameters in $\mathrm{C} 7$ were used in the analyses presented here (Table 1). While some DOC data were available from prior to 1993 , only $17 \mathrm{yr}$ of data (1993-2010) were used in this study to facilitate comparison between $\mathrm{C} 2, \mathrm{C} 4$ and $\mathrm{C} 7$. The streams were sampled weekly or biweekly and analysed for DOC, metals and other water quality parameters (Table 1) as described in previous studies (Cory et al., 2007; Köhler et al., 2008, 2009; Laudon et al., 2011; Winterdahl et al., 2011a). DOC samples prior to 1993-1994 were analysed using a Dohrmann Carbon Analyzer while samples from 1995 onward were analysed using a Shimadzu TOC 5000 (Köhler et al., 2008). Differences existed in the frequency of DOC sampling in the catchments 
Table 2. The significance of monthly and long-term MKT statistics from riparian soil transect lysimeter (S4) at various soil depths near C2 stream (approximately $4 \mathrm{~m}$ ). The symbol $\dagger$ denotes that lysimeter at $10 \mathrm{~cm}$ depth was excluded from the MKT test due to low statistical power. The values in italics represented significant declines and bold highlights represent significant monotonic increasing trends.

\begin{tabular}{|c|c|c|c|c|c|c|c|c|c|c|c|c|c|c|c|c|}
\hline \multirow{3}{*}{\multicolumn{2}{|c|}{ Group }} & \multirow[b]{3}{*}{ Parameter } & \multirow[b]{3}{*}{$\begin{array}{c}\text { Mean } \\
\left(\mathrm{mg} \mathrm{L}^{-1}\right)\end{array}$} & \multicolumn{13}{|c|}{ Mann-Kendall trend (MKT) statistics } \\
\hline & & & & \multicolumn{12}{|c|}{ Monthly } & \multirow[b]{2}{*}{$\begin{array}{l}\text { Long } \\
\text { term }\end{array}$} \\
\hline & & & & Jan & Feb & Mar & Apr & May & Jun & Jul & Aug & Sep & Oct & Nov & Dec & \\
\hline \multirow{3}{*}{ 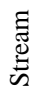 } & \multirow{3}{*}{$\begin{array}{l}\bar{O} \\
\text { ঠ }\end{array}$} & C2 stream [DOC] & 15.14 & & & & 0.099 & & & & 0.072 & 0.054 & 0.099 & 0.009 & & $<0.01$ \\
\hline & & $\mathrm{C} 4$ stream [DOC] & 31.00 & & & & & & & & 0.034 & 0.007 & 0.059 & & & \\
\hline & & C7 stream [DOC] & 20.81 & & & & & & & & 0.017 & 0.014 & 0.011 & & & \\
\hline \multirow{6}{*}{ 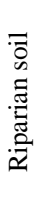 } & \multirow{6}{*}{$\begin{array}{l}\bar{\circlearrowright} \\
\text { అ }\end{array}$} & $\mathrm{S} 4 \_10(10 \mathrm{~cm}$ depth $) \dagger$ & 69.31 & & & & & & & & & & & & & \\
\hline & & $\mathrm{S} 4 \_25$ (25 cm depth) & 59.26 & & & & 0.006 & 0.050 & & & & & & & & 0.041 \\
\hline & & S4_35 (35 cm depth) & 29.74 & & & & 0.024 & & & & & & & & & \\
\hline & & S4_45 (45 cm depth) & 22.08 & & & & 0.050 & & & & & & 0.040 & & & \\
\hline & & S4_55 (55 cm depth) & 19.37 & & & & & & & & & & & & & \\
\hline & & $\mathrm{S} 4 \_65(65 \mathrm{~cm}$ depth $)$ & 22.88 & & & & 0.024 & 0.039 & & & & & & & 0.021 & \\
\hline
\end{tabular}

(C7 > C4 > C2). In each catchment, the frequency of sampling was highest in the spring and more intense in the earlier than the later part of the record.

Soil water [DOC] from the S4 riparian soil transect lysimeter from 2002-2011 was used to trace the pathways of DOC in the riparian-stream conduit. Soil solution chemistry samples were obtained from three soil profiles, established in 1996 along a $25 \mathrm{~m}$ transect in C2 (Laudon et al., 2004b; Cory et al., 2007). These profiles were at a distance of $4 \mathrm{~m}$ (S4), $12 \mathrm{~m}$ (S12) and $22 \mathrm{~m}$ (S22) from the C2 stream. The transect was aligned based on the topography to follow the assumed lateral flow paths of the groundwater toward the stream. Only the S4 lysimeter located a distance of $4 \mathrm{~m}$ from the stream was used in this study. Samples were collected from the S4 suction lysimeter at a series of depths between 10 and $65 \mathrm{~cm}$ denoted as S4_10 to S4_65 in this study (Table 2). The S4 profile was dominated by organic material with a transition from organic to organic rich mineral soil at $30 \mathrm{~cm}$ depth. The organic enrichment continues to a depth of $60 \mathrm{~cm}$.

\subsection{Data analysis}

A principal components analysis (PCA) of all chemical parameters was performed to evaluate the overall pattern of the relationships between the water quality parameters in the catchment over time. This was followed by Mann-Kendall trend test (MKT) analysis to assess the significance of monotonic trends (increase and/or decrease) in runoff, weatherrelated parameters, stream [DOC], trace metals, base cations and atmospheric deposition chemistry. This analysis was conducted on the monthly average values of the raw data. Annual as well as monthly trends were calculated since many water quality time series are characterized by strong seasonal variation. The MKT test is ideal for fulfilling the objectives of this study as it is a robust non-parametric statistical method that has been widely used to detect temporal changes in water quality (Lepistö et al., 2008; Libiseller and Grimvall, 2002; Worrall et al., 2004; Yue et al., 2002). The MKT test is insensitive to missing values and outliers in the data set or seasonality, autocorrelation and non-normality of the water quality data sets (Evans et al., 2005; Worrall et al., 2004). Sen's slope was also calculated from monthly data to show rates of change in long-term deposition and stream chemistry data. Soil solution [DOC] from S4 lysimeters were similarly subjected to MKT tests on both a seasonal and long-term basis. Seasonal MKT tests were performed using MULTMK/PARTMK (Libiseller and Grimvall, 2002) and annual trends with MAKESEN (MKT test and Sen's Slope estimates) (Salmi et al., 2002). Change in growing degree days and growing season length were also calculated. Growing degree days were estimated as the sum of air temperature for all days in a year where temperature was above a threshold of $5^{\circ} \mathrm{C}$. The growing season length was based on the number of days with air temperature greater than $5^{\circ} \mathrm{C}$.

\section{Results}

\subsection{Change in climate, runoff and growing season}

Our results showed that the temperature time series was not homogenous as years 1985-1987 were colder (due to cold winter periods) while 1981-1984 and 1989 onward were warmer (Fig. 2). The long-term mean air temperature was $1.7^{\circ} \mathrm{C}$ (1981 to 2008) with a mean January temperature of $-9.5 \pm 4.1^{\circ} \mathrm{C}$ and a mean July temperature of $14.5 \pm 1.7^{\circ} \mathrm{C}$. Annual mean stream water temperature was $3.5 \pm 0.7^{\circ} \mathrm{C}(1987-2011)$. The annual precipitation was $610 \pm 109 \mathrm{~mm} \mathrm{yr}^{-1}$. The temporal pattern in annual runoff was similar to precipitation, with the largest variability between 1997-2002 (Fig. 3). Specific discharge was approximately $320 \pm 97 \mathrm{~mm} \mathrm{yr}^{-1}$.

There was a significant monotonic increasing trend in air temperature $(\mathrm{MKT}=3.03, p<0.05)$ with a Sen's slope 

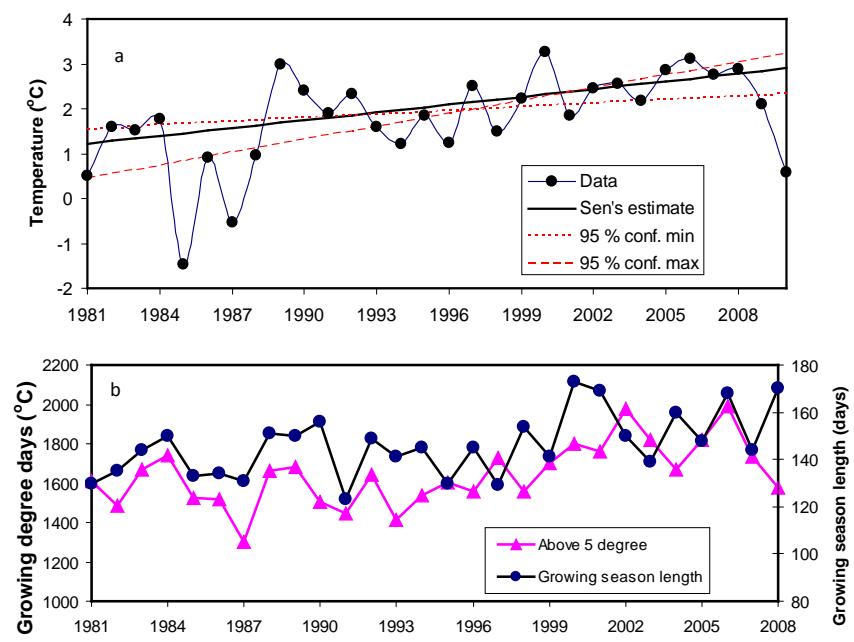

Fig. 2. (a) Pattern and non-homogeneity of air temperature series with the long-term trend and Sen's Slope estimate as summarized in Table 2 and (b) plot of change in growing season length (days) at $T>5^{\circ} \mathrm{C}$ and corresponding change in growing degree days above 5 degree. Long-term average growing season length changed from 140 days (1981-1999) to 156 days (2000-2008). There are significant monotonic increases in both growing season length $(\mathrm{MK}=2.26, p<0.05)$ and change in degree days above 5 degree $(\mathrm{MK}=2.90, p<0.05)$.

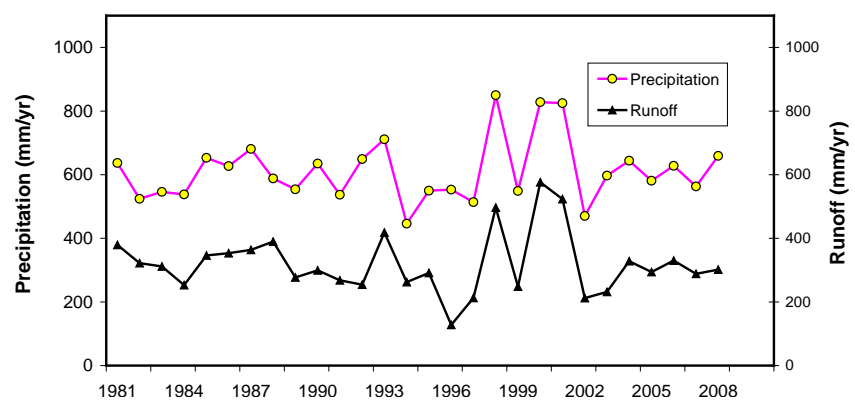

Fig. 3. Temporal variations and trend in long-term weather data in Svartberget catchment showing a non-significant monotonic trend in the long-term precipitation and runoff series in C7.

of $0.058^{\circ} \mathrm{C} \mathrm{yr}^{-1}$ (Fig. 2) over the $27 \mathrm{yr}$ period. In addition to the overall trend, monthly air temperature showed significant increases in January, April, August, September and December. Change in growing season was also evaluated for the entire period (Fig. 2). There was a significant monotonic increase in growing degree days above $5{ }^{\circ} \mathrm{C}(\mathrm{MKT}=2.90, p<0.05)$ and growing season length increased from 140 days (1981-1999) to 156 days (2000-2008) (Fig. 2). Water temperature followed a similar overall monotonic increase at the $p<0.05$ level (Table 1). The increase in monthly water temperature was statistically significant in most months except February, October, November and December. Unlike air temperature, no statistically significant overall trend could be detected in long-term precipitation series but there was a borderline decline in October monthly precipitation at $p<0.1$ (Table 1 ). No detectable trend was observed for long-term runoff series, but trends in monthly flows do exist. There was an increase in March $(p<0.05)$ and decline in May and October $(p<0.1)$ monthly flows. These trends were consistent with warmer temperatures leading to earlier spring melt and possibly greater summer evapotranspiration.

\subsection{Atmospheric deposition chemistry}

In terms of precipitation chemistry, atmospheric deposition in Svartberget is low with long-term depositional fluxes of $0.08 \pm 0.05 \mathrm{~g} \mathrm{~m}^{-2} \mathrm{yr}^{-1}$ for calcium, $\quad 0.02 \pm 0.008 \mathrm{~g} \mathrm{~m}^{-2} \mathrm{yr}^{-1}$ for magnesium, $0.09 \pm 0.03 \mathrm{~g} \mathrm{~m}^{-2} \mathrm{yr}^{-1}$ for sodium, $0.21 \pm 0.07 \mathrm{~g} \mathrm{~m}^{-2} \mathrm{yr}^{-1}$ for sulfate-S and $0.32 \pm 0.1 \mathrm{~g} \mathrm{~m}^{-2} \mathrm{yr}^{-1}$ for DIN (Fig. 4). The low levels of acid deposition suggest that the catchment is only slightly acidified and thus subtle effects of recovery from acidification may be influencing stream water chemistry. Our results showed a significant long-term decline in the annual deposition of magnesium $(\mathrm{MKT}=-2.12$, $p<0.05)$, calcium $\quad(\mathrm{MKT}=-1.89, \quad p<0.1)$, sodium $(\mathrm{MKT}=-1.74, p<0.1)$, sulfate $(\mathrm{MKT}=-1.74, p<0.1)$ and DIN (MKT $=-2.27, p<0.05$ ) (Fig. 4).

\subsection{Long-term patterns and trends in DOC concentration}

\subsubsection{Stream DOC concentrations}

Both the pattern and magnitude of stream DOC variability were significantly different in the three streams (Fig. 5). The highest [DOC] was observed in the wetland dominated $\mathrm{C} 4$ with a flow-weighted [DOC] of $27 \pm 7.1 \mathrm{mg} \mathrm{L}^{-1}$ (un-weighted $=31 \pm 5.5 \mathrm{mg} \mathrm{L}^{-1}$ ). The lowest [DOC] was observed in the upland forest $\mathrm{C} 2$ with a flow-weighted concentration of $19 \pm 3.8 \mathrm{mg} \mathrm{L}^{-1}$ (un-weighted $=15 \pm 2.8 \mathrm{mg} \mathrm{L}^{-1}$ ). The $\mathrm{C} 7$ stream draining both forest and mire landscape elements has an intermediate flow-weighted stream [DOC] of $23 \pm 3.6 \mathrm{mg} \mathrm{L}^{-1}$ (unweighted $=21 \pm 3.7 \mathrm{mg} \mathrm{L}^{-1}$ ).

We observed a change in both concentration and seasonal variability of DOC (Fig. 5). There appeared to be a shift in the magnitude of variability in spring [DOC] around 2002 and an increasing [DOC] during summer baseflow in $\mathrm{C} 2$ (Fig. 5). Similar shifts in magnitude of spring [DOC] were observed in $\mathrm{C} 7$ with a corresponding increasing trend in the low DOC values associated with the summer baseflow condition but the change occurred around 2004 instead. The shift in variability of [DOC] was synchronous with the long-term shift in the magnitude of daily runoff variability between the earlier and later part of the record. This corresponds to the longer growing seasons observed post-2002 (Fig. 2). Differences exist between the seasonal dynamics of DOC in the 

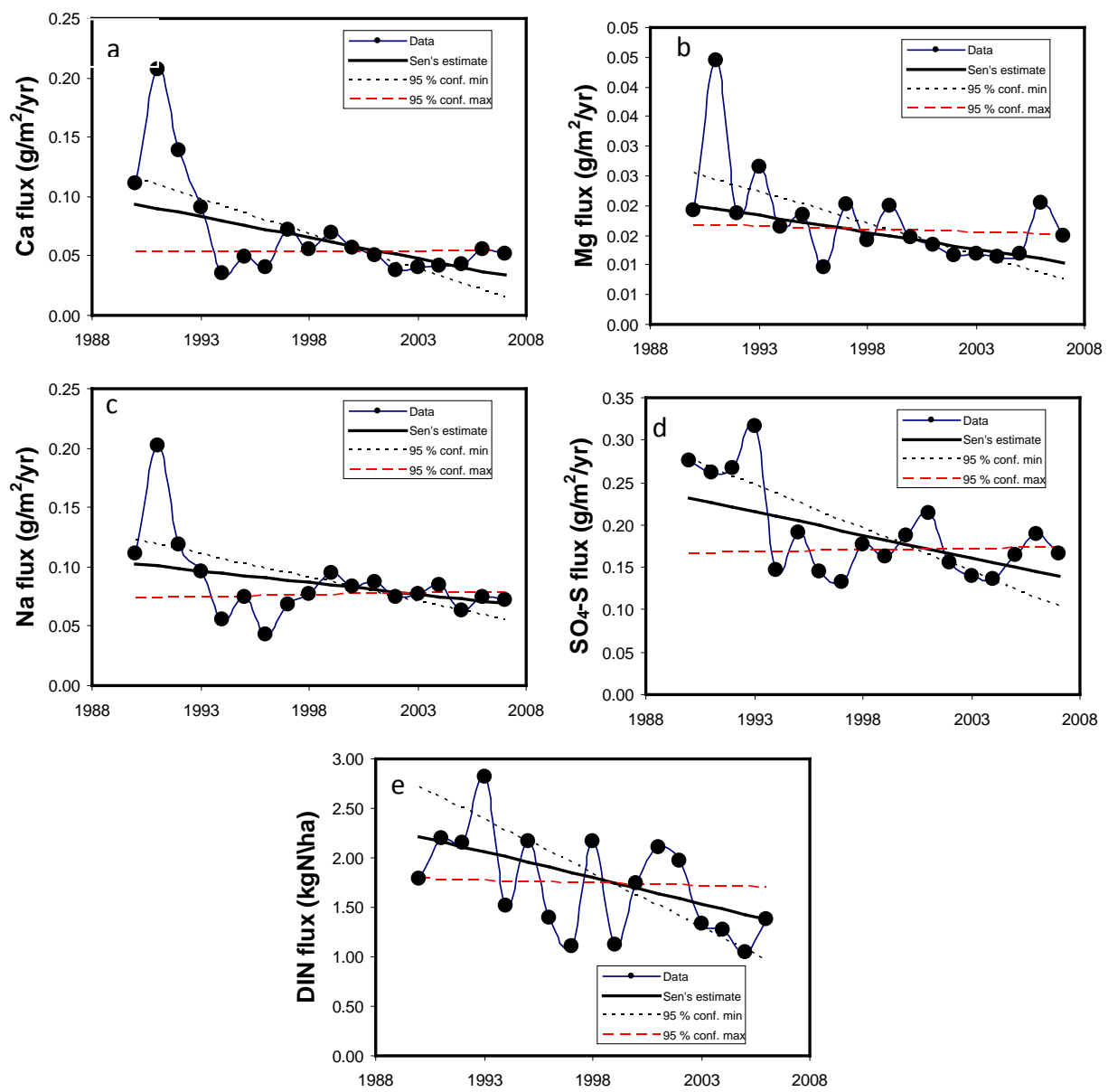

Fig. 4. Long-term pattern and the significance of trend in the annual depositional fluxes of Calcium (a), Magnesium (b), Sodium (c), Sulfate (d) as well as dissolved inorganic nitrogen (e).

three catchments. While a dilution effect dominates in $\mathrm{C} 4$ in spring, both $\mathrm{C} 2$ and $\mathrm{C} 7$ showed [DOC] increased with runoff.

There were no detectable overall trends in [DOC] in either $\mathrm{C} 4$ or C7. However, significant monotonic trends exist in C2 (Table 1). Stream [DOC] at all sites showed significant positive trends in autumn but only $\mathrm{C} 2$ showed an overall increase in concentration over the long-term. In addition to the autumn increase, there were positive trends in [DOC] in April and November in C2 (Table 1). The lowest spring [DOC] in $\mathrm{C} 4$ was observed in May, corresponding to the month with the highest spring runoff. There was also a slight increase in DOC leaching from the mire in March prior to the onset of the spring melt.

The hydrological responses of the three catchments were different. Non-linear relationships existed between the stream [DOC] and specific discharge (Fig. 6). While logarithmic relationships existed between the stream [DOC] and runoff in $\mathrm{C} 2$ and $\mathrm{C} 7$, the relationship is more complex in the mire dominated $\mathrm{C} 4$ (Fig. 6). The flow-[DOC] relationship at $\mathrm{C} 4$ showed that runoff alone cannot account for variability in both the low spring and high summer [DOC]. DOC pro- duction and concentration in $\mathrm{C} 2$ and $\mathrm{C} 4$ appeared to respond almost linearly to increasing runoff until a specific discharge of about $0.5 \mathrm{~mm} \mathrm{day}^{-1}$ (in C2) or $0.2 \mathrm{~mm} \mathrm{day}^{-1}$ (in C7) is reached. At this threshold, additional runoff does not seem to cause any further increase in [DOC]. Therefore, runoff explained up to $44 \%$ of the variability in [DOC] in the forest dominated $\mathrm{C} 2$ catchment but only $22 \%$ in $\mathrm{C} 7$ draining the mixed landscape (Fig. 6).

\subsubsection{Riparian soil DOC concentrations}

Riparian soil water from the S4 suction lysimeter array was used to evaluate long-term patterns of riparian soil [DOC] and possible controls on stream [DOC] (Fig. 7). These lysimeters were placed at various soil depths $(10-65 \mathrm{~cm})$ at an interval of $10 \mathrm{~cm}$ (Table 2). Too few data were available from the S4_10 lysimeter placed at $10 \mathrm{~cm}$ to run the MKT test, so it was therefore excluded from the analysis (Table 2). Concentrations of DOC in the S4_25 lysimeter placed at $25 \mathrm{~cm}$ soil depth showed an overall borderline decline $(p=0.041)$ and in April $(p<0.01)$ and May monthly values 

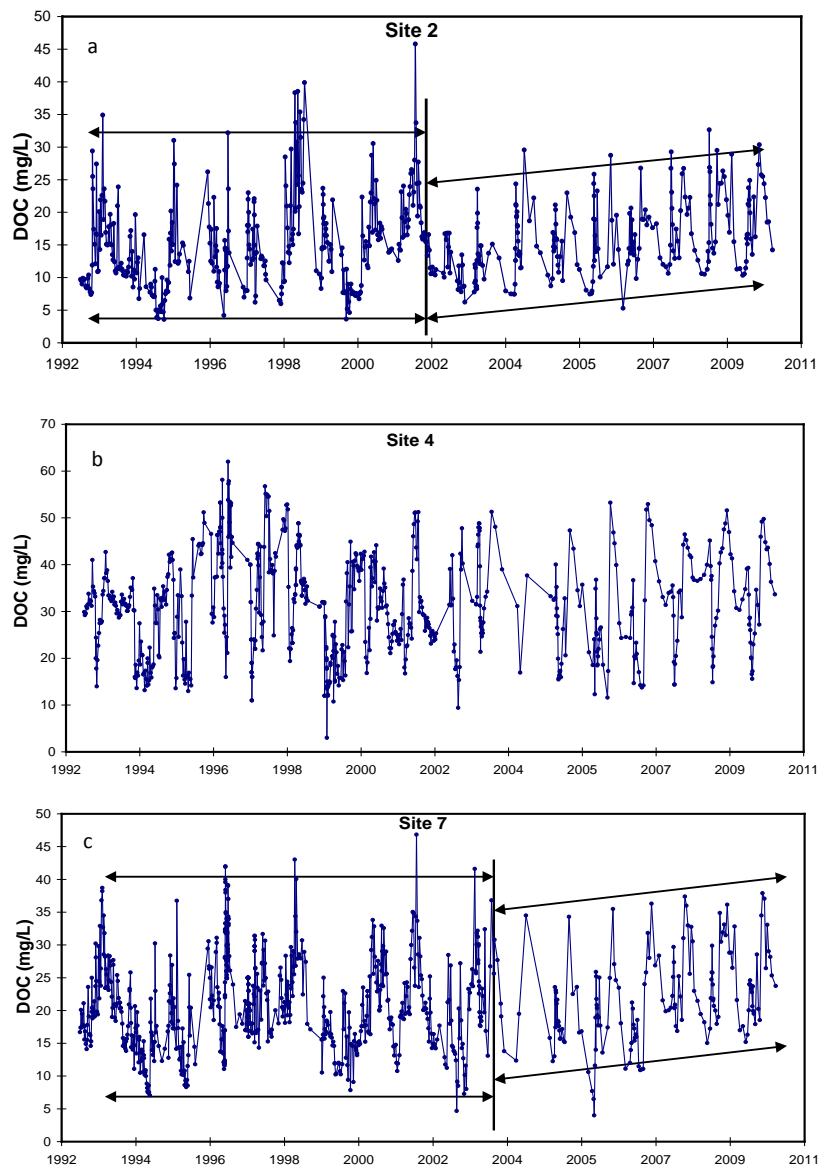

Fig. 5. Long-term series of stream [DOC] in (a) forest dominated C2 stream (b) mire drained C4 stream and (c) C7 draining both forest and mire landscape elements.

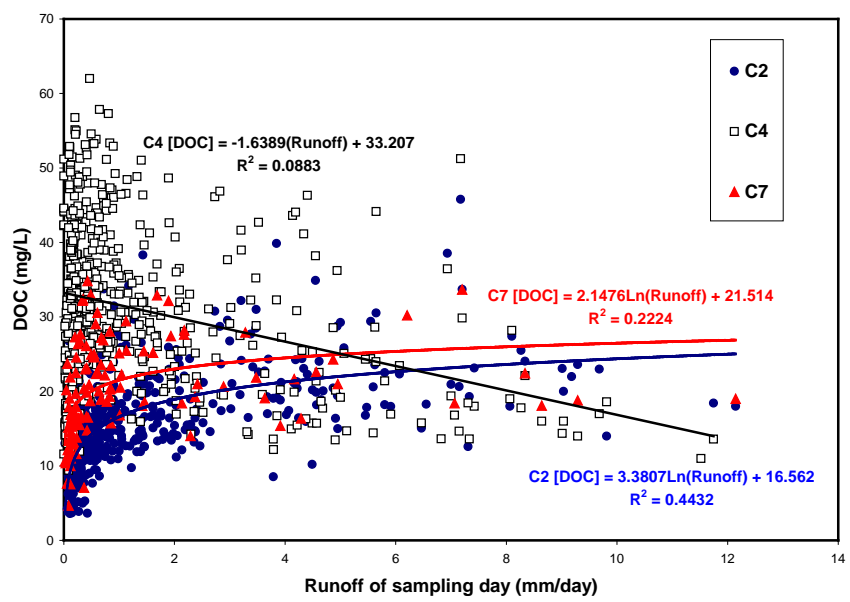

Fig. 6. Long-term pattern of runoff controls on stream DOC concentration in $\mathrm{C} 2, \mathrm{C} 4$ and $\mathrm{C} 7$ catchments.

$(p=0.050)$. Lysimeter S4_35 at a depth $35 \mathrm{~cm}$ showed no detectable overall trend but a significant increase was observed in April monthly concentrations $(p=0.024)$. Lysime-
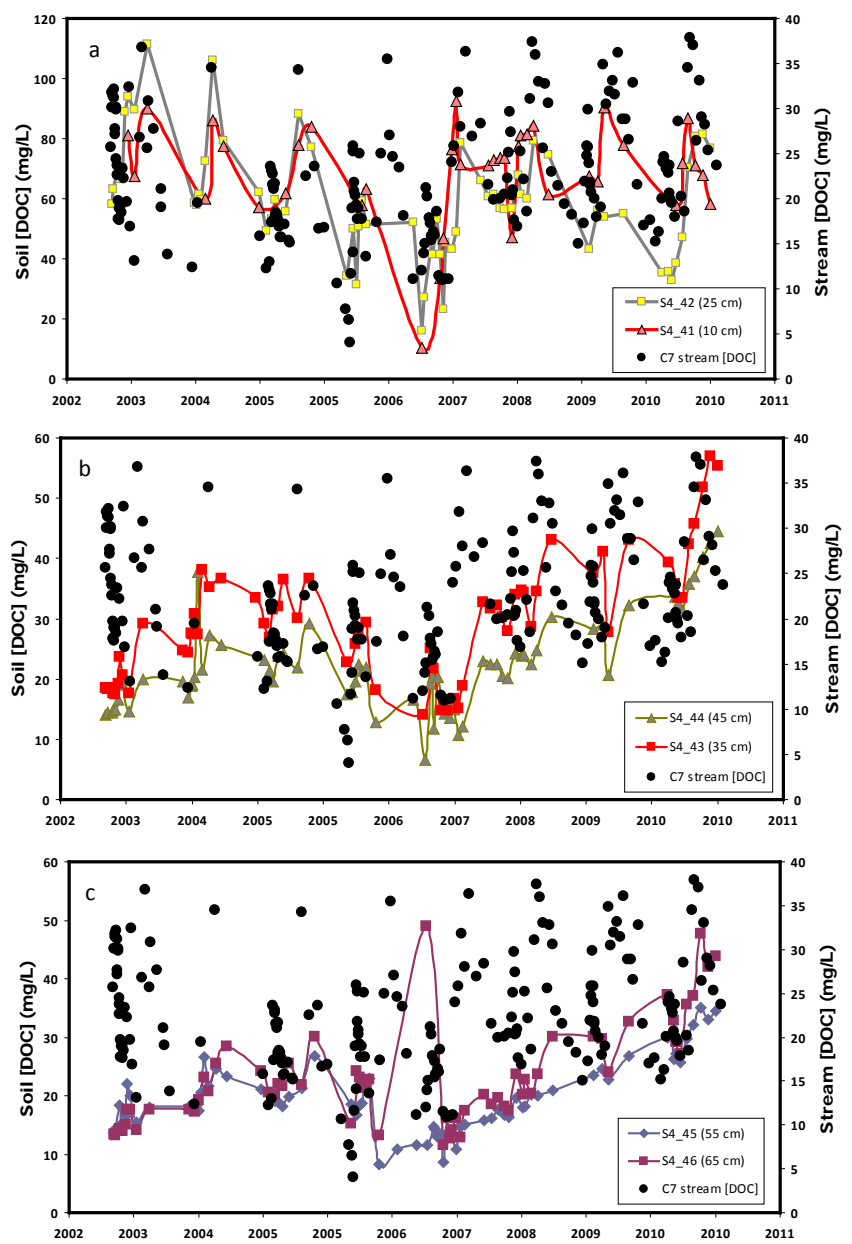

Fig. 7. Riparian soil solution profile from $\mathrm{S} 4$ lysimeter and $\mathrm{C} 2$ stream [DOC] at the depths of $10-25 \mathrm{~cm}$ (a), 35-45 cm (b) and $55-65 \mathrm{~cm}(\mathbf{c})$.

ter S4_45 placed at $45 \mathrm{~cm}$ depth showed a borderline increase in April and October monthly concentrations $(p \leq 0.05)$ but no detectable trend was observed (both on monthly and overall) in the S4_55 lysimeter placed at a depth of $55 \mathrm{~cm}$ in the riparian soil. In contrast to S4_55, there was a statistically significant increase in [DOC] in the deepest S4_65 lysimeter at $65 \mathrm{~cm}$ soil depth. The monotonic increases were significant both overall $(p=0.02)$ as well as in April and May $(p<0.05)$.

\subsection{In-stream chemical parameters}

In addition to stream [DOC], trends in other chemical parameters were also evaluated using available long-term data from the C7 stream (Fig. 8). Annual flow-weighted mean concentration of sulfate-S and chloride in the stream were $4.56 \pm 1.34 \mathrm{mg} \mathrm{L}^{-1}$ and $0.73 \pm 0.12 \mathrm{mg} \mathrm{L}^{-1}$, respectively (Fig. 8). Stream water chemistry suggests that the catchment was slightly acidified. There was a significant increase in $\mathrm{pH}$ in spring months while sulfate and conduc- 

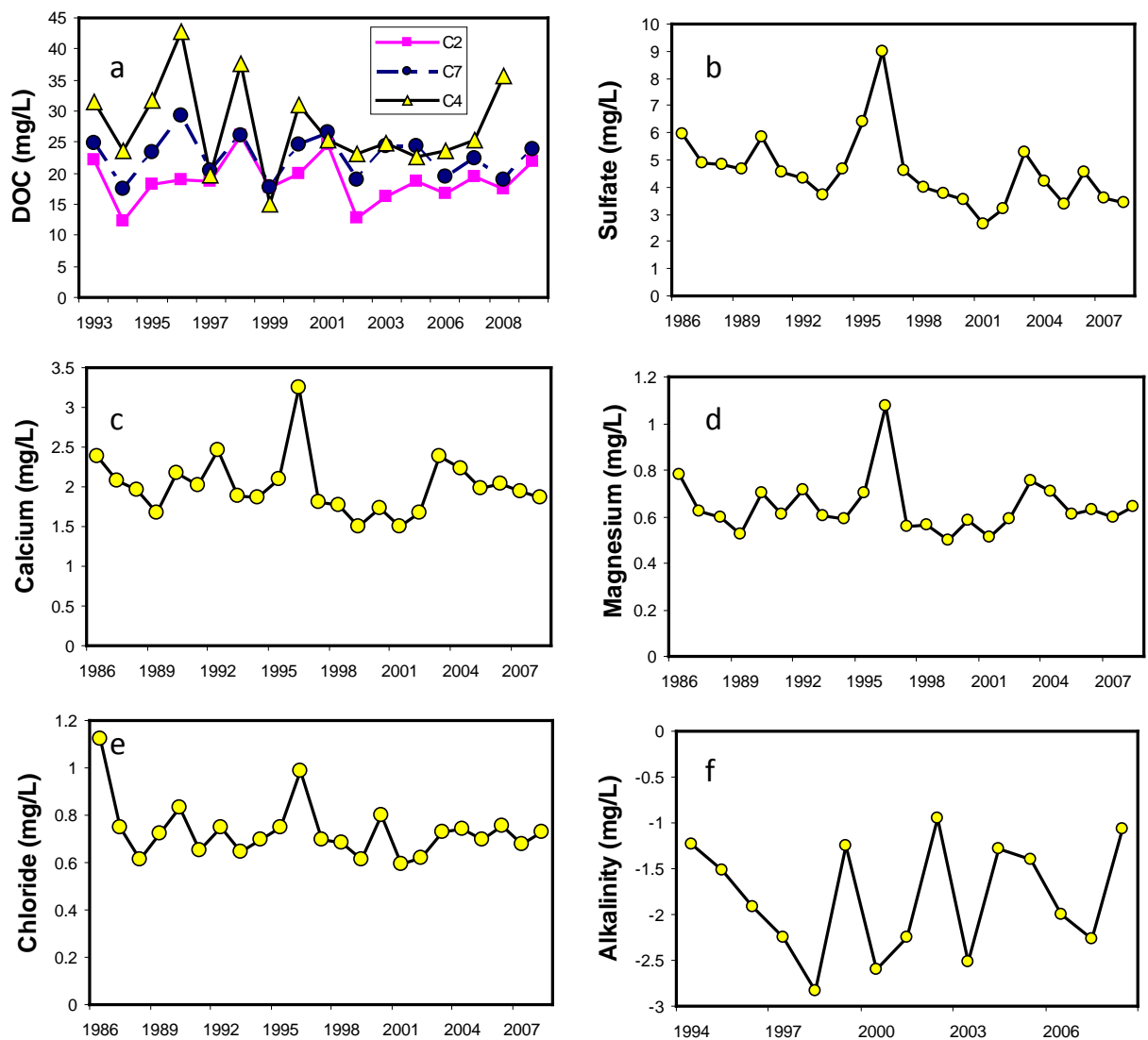

Fig. 8. Long-term pattern of flow weighted concentration of stream DOC (a), sulfate (b), base cations (c, d), chloride (e) and stream alkalinity (f).

tivity decline significantly $(p<0.05)$ over the entire study period (Table 1). The decline in alkalinity that we observed was particular to late summer-early winter months (August-December) and early spring (April-May) (Table 1). There was also a significant monotonic increase in UV absorbance in most months and on an annual scale $(p \leq 0.05)$ (Fig. 9).

\subsection{Base cations and trace metal concentrations}

The long-term, flow-weighted mean concentration of calcium was $2.0 \pm 0.4 \mathrm{mg} \mathrm{L}^{-1}$ while magnesium was $0.64 \pm 0.12 \mathrm{mg} \mathrm{L}^{-1}$ (Fig. 9). When the un-weighted concentrations of base cations were subjected to MKT tests, our results showed that calcium and magnesium displayed monotonic declining trends in most months and overall (Table 1). The decline in calcium was observed in most months except June and October $(p<0.05)$. The decline in monthly magnesium concentrations mostly occurred in winter and early spring (December-April) after which no trend was detected until August (Table 1). No annual and monthly trends were observed in sodium concentrations, except for monthly concentrations in June $(p<0.05)$. No overall trend was ob- served in potassium but increasing trends exist in March $(p<0.05)$ in contrast to declining trends in April and May.

Trace metals also showed significant long-term trends with both monotonic declines (copper and zinc) and increases (iron) observed at a $p=0.05$ probability level (Table 1 ). Both zinc and copper decline significantly in most months. However, we observed a unique pattern in monthly iron concentrations, where increases were observed in August to December (Table 1). This is mostly consistent with the period where we observed significant increases in stream [DOC]. No major change in long-term silica concentrations were observed except the borderline decline (in February and April) and increase (in December) at $p<0.1$ level.

The overall pattern of relationships from the PCA showed that stream [DOC] was negatively correlated with many other water quality parameters, including base cations and positively correlated with trace metals (Fig. 10). A strong correlation existed between DOC and UV absorbance. Temperature was also related to DOC on the first principal component axis. Zinc, copper and iron are orthogonal to the first principal axis while iron and temperature were close to the centre of the axes. 


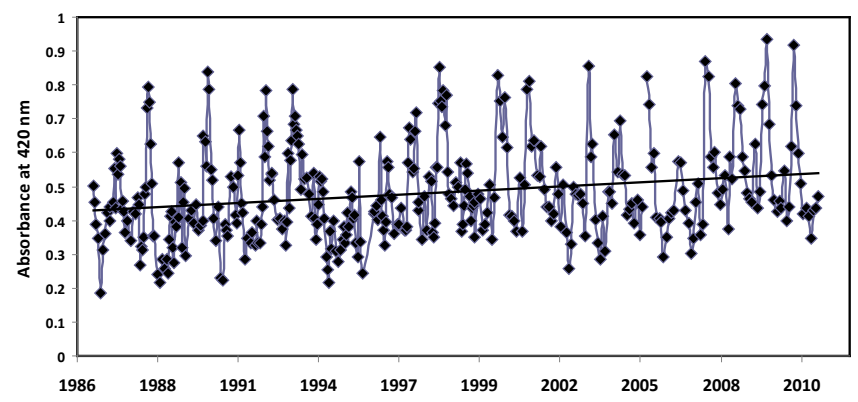

Fig. 9. Long-term series of UV absorbance at $420 \mathrm{~nm}$ in C7.

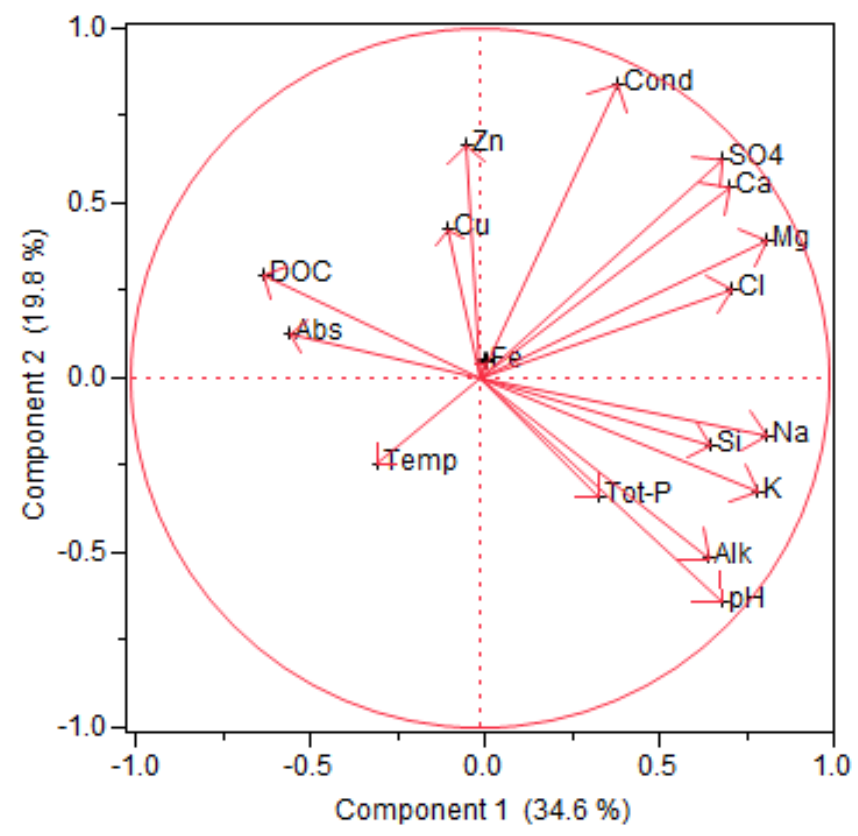

Fig. 10. Principal component analysis (on correlations) showing the overall pattern of relationships in the $\mathrm{C} 7$ long-term chemical parameters used in this study.

\section{Discussion}

\subsection{Climate control on DOC}

The drivers of long-term trends in headwater stream chemistry can be both process and scale dependent (Clark et al., 2010). A recent long-term, cross-regional scale study by Laudon et al. (2012) concluded that long-term average stream $[\mathrm{DOC}]$ is related to the prevailing mean annual temperature on a regional scale. When catchments across a $1000 \mathrm{~km}$ latitudinal gradient between Northern and Southern Sweden were compared, temperature and discharge both appeared as major controls, but differed in their importance for specific catchments (Winterdahl et al., 2011b; Futter et al., 2011). However, no consensus on how climatic factors are affecting stream chemical parameters in individual catchments has been reached for the northern boreal ecozone. The almost three decades of temperature measurements for the Svartberget showed that the region is moving towards warmer conditions (Fig. 2).

Large natural variability exists in precipitation and runoff patterns over the period of record (Fig. 3). There was a shift in the magnitude of variability in the spring runoff hydrograph by about $17 \%$ between 1992-2002 and 2002-2008. The shift in the magnitude of variability in runoff can be attributed to a long-term monotonic increase in temperature, decline in snowpack and a longer growing season (Fig. 2). The warmer temperatures and longer growing season would suggest that a smaller fraction of precipitation has fallen as snow in recent years, and the magnitude of the spring runoff peak may be reduced. This shift in runoff regime can further explain the reduction in the amplitude of spring [DOC] variability in the late period in contrast to early period of record where there was high variability (Fig. 5). The drop in the flashy spring [DOC] in the later period of record in (C2 and C7) suggests that stream DOC is driven more by intermittent rainfall flushing the top or subsurface layers than prolonged soil inundation from rising groundwater levels. This might have large implications for the catchment carbon dynamics as changing flowpaths can influence the sources and mobilization of carbon and other carbon dependent processes (Laudon et al., 2011). There were pronounced differences in year-to-year runoff regime (1997-2002) in the catchment as some years were very wet while others were very dry (Fig. 3).

Stream [DOC] responds differently to runoff as spring dilution was observed in wetland dominated $\mathrm{C} 4$ while increases in [DOC] were observed in the forest dominated $\mathrm{C} 2$ as reported earlier by Köhler et al. (2008). The C4 dilution can be attributed to less water infiltrating and subsequent reduced contact time with peat (Laudon et al., 2011; Yurova et al., 2008). Similar autumn dilution pattern in C7 (Köhler et al., 2008) can be attributed to the influence of the upstream mire during the autumn season. The autumn dilution behaviour has been attributed to late summer or early autumn rainfall (Köhler et al., 2008). This is also expected in $\mathrm{C} 7$ as the effect of forest and wetland are combined in the catchment despite similar seasonal trends. This explains why runoff can only explain about $22 \%$ of the total variability in [DOC] in the C7 stream (vs. $44 \%$ in C2) despite the large hydrologic changes. It appears that the presence of wetlands stabilises or offsets the hydrologic changes associated with dry-wet regimes in C4. The increases in DOC during snowmelt in $\mathrm{C} 2$, especially in April where we observed a monotonic increase (Table 2), can be as a result of the influences of the riparian processes in upland forest catchments (Ågren et al., 2010).

\subsection{Riparian controls on stream DOC concentration}

The riparian soil-stream interface is important for DOC production in boreal forest catchments due to the strong hydrological connectivity between the soil, groundwater and 
surface waters (Laudon et al., 2011). The timing and change in groundwater levels can be an important driver of fluxes through the riparian zone, which have a strong influence on in-stream [DOC] (Bishop et al., 1995; Lyon et al., 2011; Grabs et al., 2012). Typically, soil solution [DOC] exceeds stream [DOC] and decreases with depth down the soil profile (Köhler et al., 2009). This apparent disconnect in soil and streamwater concentrations might be accounted for by vertical differentiation in the flux of water through the riparian zone (Bishop et al., 1993). The Riparian Profile Integration Model (RIM, Seibert et al., 2009) uses this interaction of flow and concentration in the riparian profile to predict stream [DOC] (Winterdahl et al., 2011a, b). The increase over time in soil solution $[\mathrm{DOC}]$ in the deeper riparian soil layer may be the result of changing long-term patterns in weather and runoff.

Because the S4_10 lysimeter was dry during most sampling visits, there was not enough data available for a statistical test of trends in [DOC] concentrations in the topmost soil layer. However, useful inferences can be drawn from the S4_25 lysimeter. Declining trends in riparian soil solution [DOC] in S4_25 during snowmelt in April and May suggested either more complete flushing of a limited DOC pool or declines in the rate at which DOC could be produced in the spring in more recent years. The drop in the flashy spring DOC from the upper soil layers suggests that stream DOC is driven more by intermittent rainfall flushing the top or subsurface layers than prolonged soil inundation from rising groundwater levels. This can further explain the reduction in the amplitude of spring [DOC] variability in the late period in contrast to early period of record where there was higher variability (Fig. 5). The increase in soil [DOC] in October observed in the S4_45 lysimeter might have driven $\mathrm{C} 2$ stream [DOC] toward the significant increases observed in November. The increases in stream water [DOC] during snowmelt, especially in April where we observed a monotonic increase, can be under the control of riparian processes in forest dominated catchments (Ågren et al., 2010).

We observed significant increasing trends in soil solution [DOC] in lysimeters at depths of $55-65 \mathrm{~cm}$. The upward swing in the riparian [DOC] at this depth and corresponding increase in stream baseflow [DOC] (Fig. 7) is an indication of an increased contribution of riparian deep-soil layers to stream [DOC]. This suggests an increasing influence of temperature on riparian soil processes (Winterdahl et al., 2011a). The temperature effect might explain why we also observed significant increasing trends in soil solution and stream water [DOC] in April, perhaps as a result of earlier snowmelt (Tables 1 and 2).

However, a gap exists in quantifying the absolute contribution of each riparian layer so as to ascertain how riparian zones influence adjacent stream [DOC] both laterally and vertically down the soil profile. Since our study period is characterized by a series of contrasting wet-dry year regimes, the onset of wetter years that followed some of the driest years on record could set the stage for the increasing trend and variability in stream [DOC] that we observed. Prolonged wet periods in the riparian soil lead to statistically significant increases in soil water [DOC] (Köhler et al., 2009). Our results showed that dry-wet cycle has pronounced effects on [DOC] in intermittent $\mathrm{C} 2$ stream, which might be more susceptible to drought conditions. However, rewetting of soils and flushing of accumulated DOC in the subsequent wetter year might lead to a significant increase in the overall [DOC] trend at $\mathrm{C} 2$. Though increases in air temperate and associated increases in evapotranspiration might plausibly indicate drier soils in the future, this needs to be investigated further to complement the earlier modelling concept of riparian flowconcentration integration (Seibert et al., 2009; Winterdahl et al., 2011a, b).

\subsection{Trends and variations in deposition, climate and stream DOC concentration}

Our study site is located in a region that has only been minimally impacted by anthropogenic acid deposition as only episodic acidification during spring snowmelt and autumn episodes has previously been reported (Bishop et al., 1990, 2000; Laudon et al., 1999; Laudon and Hemond, 2002). Svartberget has not been regarded as an acidified catchment since stream $\mathrm{pH}$ must have dropped by at least 0.4 units for a site to be classified as acidified in Sweden (Fölster et al., 2007; SEPA, 2007). Furthermore, most of the recovery from anthropogenic acidification in the area occurred already in the early 1990s when the large decline in acid deposition occurred (Laudon and Bishop, 2002). Therefore, the acidification recovery hypothesis of Monteith et al. (2007) might contribute in part but is not likely to be a dominant controlling factor of the long-term stream [DOC] pattern that is observed in the Svartberget streams.

While no detectable overall monotonic trends in precipitation and runoff were observed (Fig. 2), significant trends existed for individual months (Table 2). Runoff showed a significant increase in March and declined in May. This suggests earlier snowmelt in recent years. Temperature and moisture are important drivers of autumn DOC (Preston et al., 2011). The significant monotonic increase in [DOC] that we observed in autumn can therefore be attributed to biological controls such as microbial enzymatic activities that convert humified organic matter to leachable organic carbon that are more important under wetter and warmer conditions (Berggren et al., 2008). This suggests that DOC production is becoming more dependent on runoff and antecedent soil temperature, as temperature showed a significant increase in August and September (Table 2). The significant increase in autumn [DOC] at the upland forest site can also be explained as forests are expected to have permeable soils and high rates of evapotranspiration. However, it is not fully clear what is simultaneously driving the autumn increase in $[\mathrm{DOC}]$ in the mire dominated $\mathrm{C} 4$ study site despite its contrasting autumn 
DOC dilution mechanism. Our observed increase in autumn [DOC] is in agreement with some other studies carried out elsewhere using similar small headwater catchments (e.g. de Wit et al., 2007; Preston et al., 2011). However, the dominant drivers of the biogeochemical processes behind the autumnal increase might be different. De Wit et al. (2007) attributed the response of autumn DOC in a Norwegian catchment to the effect of reduction in acid deposition. Preston et al. (2011) attributed the autumnal increase in DOC over their $29 \mathrm{yr}$ record in south-central Ontario catchment to hydrologic and temperature change. They observed that stream [DOC] was negatively correlated with autumn runoff and precipitation. The significant trend in autumnal DOC might therefore result from little loss to degradation (either microbially or photolytically) in the streams (Köhler et al., 2002).

\subsection{Linkage between deposition, stream DOC and other chemical parameters}

We cannot totally rule out the subtle effects of catchment recovery from acidification on stream water chemistry since we have observed an increase in spring $\mathrm{pH}$ and a decline in sulfate. This finding is consistent with previous work by Laudon and Bishop (2002) and Laudon and Hemond (2002) on episodic acidification in the catchment. The pulse of stream acidity during snowmelt is a result of acid deposition on the snowpack during winter which is washed down to streams during the spring melt. Winter sulfate lowers acid neutralizing capacity and will cause $\mathrm{pH}$ to decrease. Therefore, catchment recovery from acidification can increase stream [DOC] (Monteith et al., 2007). However, deposition in our site is low and is even further declining (Fig. 3). Declines in stream base cation concentration in response to reductions in acid deposition have been reported (e.g. Watmough and Dillon, 2001; Watmough et al., 2005). General declining trajectories of stream base cation concentration in our site (Fig. 4) also suggest a recovery from the effects of acidification. Alkalinity is a conservative parameter that is not influenced by temperature. Therefore, the decline in sulfate and base cation during other times of the year which is not accompanied by a change in $\mathrm{pH}$ and alkalinity is also consistent with a change (recovery from non-acidified state) driven by declining sulfate deposition. This would be consistent with the classic inorganic model of acidification (e.g. Galloway et al., 1983) where the decline in anionic deposition leads to a reduction in co-transport of base cations.

Calcium has been identified as one of the base cations that is most at risk of depletion in boreal catchments (Thiffault et al., 2011). Calcium is declining in Canadian boreal streams (Watmough and Dillon, 2003; Watmough et al., 2005). Therefore, significant decline in calcium (both overall and monthly) in our catchment can be attributed to depleting soil reserves in the catchment as a result of continuous leaching and/or intermittent drought-like conditions induced by several dry-wet years in our study. Declining soil water calcium can reduce DOC adsorption in mineral soils through a cation bridging mechanism and as a result contribute to long-term increasing DOC trends in streams draining upland catchments (Kerr and Eimers, 2012). This is because sorption equilibrium is an important mechanism controlling DOC at the soil-water interface. Stores of calcium can increase at the same time as runoff concentrations decrease if there are less counter ions to desorb and transport calcium ions to the stream. Significant declines in potassium in the spring can be as a result of low capacity of the catchment soil to retain potassium ions leached from the plant residues (Thiffault et al., 2011). Our results showed that sodium had no significant monotonic trend either monthly (except June) or overall. It has been shown that sodium has little or no effect on the DOC adsorption (Kerr and Eimers, 2012) as divalent cations (e.g. calcium) are more important in cation bridge formation than sodium which is monovalent (Munch et al., 2002).

We observed a declining trend in stream conductivity and a significant increase in $\mathrm{pH}$ especially in winter to spring months (Table 2). Reducing ionic strength that resulted from a monotonic decline in conductivity can be explained by the decrease in both sulfate and calcium during the same period. Changes in ionic strength at the soil-water interface can influence the configuration of DOC molecules (Vermöhlen et al., 2000) and could imply that winter and spring are becoming more favorable for production of soluble DOC. This might explain why there was no detectable [DOC] trend in those seasons unlike autumn, despite the increasing trend in UV absorbance (Table 2). The increasing trends in UV absorbance in most months without any correspondinding change in DOC trends may indicate a shift in DOC quality from labile to more humic-rich material. This is in contrast to a recent study by Eklöf et al. (2012) where they observed increasing DOC but no change in absorbance in some of the 19 Swedish rivers they studied.

Atmospheric deposition of trace metals decreases significantly in Sweden toward the northern part of the country (Huser et al., 2011) where our study catchment is located. We expected that most metals should increase with DOC at least in autumn (except iron) but we observed the opposite. Though the declining trend that we observed in zinc is understandable as the element has weak binding capacity with organic matter (Hernandez et al., 2006; Huser et al., 2012) and its deposition is generally declining in Northern Sweden (Huser et al., 2011). However, stream copper concentration showed a similar declining trend on both an overall and seasonal basis despite its stronger affinity to DOC. The significant declining trend in copper that we observed can be attributed more to regional controls such as non-alkaline nature of soils in the northern boreal catchments (Huser et al., 2011) as $\mathrm{pH}$ increase was not significant in most months. However, the interpretation of copper behaviour appeared to be more complicated than the complexation hypothesis stated above, as seasonal declining trends were observed in January, March, and June when there was a corresponding increase in 
pH. The recent study by Huser et al. (2011) reported a similar declining pattern in copper trends across Sweden. Landre et al. (2009) also noted that little or no relationships existed between copper and DOC, suggesting that there are more subtle processes controlling copper biogeochemistry in headwater catchments that are yet to be understood. The simultaneous monotonic increase in DOC and iron in autumn is a strong indication of co-transport of iron with DOC in the form of organometallic complexes and/or adsorption that provide stability for colloidal iron species. This is because polyvalent cations such as aluminum or iron might play a significant role in influencing the mobility of DOC in organo-mineral soils (Jansen et al., 2005; Kothawala et al., 2009). Since base cations (except sodium) and trace metals (except iron) are generally on the declining trend despite the relatively undisturbed state of our catchment, future climate and forest management might shift the trend in a more complicated direction; an indication of catchment sensitivity to disturbance.

The overview of the parameters examined in this study suggested that complex interactions existed in stream chemical parameters (Fig. 10). The clustering of base cations on the PCA axes suggest a strong geochemical weathering signal. Clustering of zinc, copper and iron together suggest a geochemical signal but their orthogonal projection to the first axis is an indication of other controlling factors than geochemical weathering. However, closeness of temperature and iron to the centre of the axes is an indication that some information is carried on other axes. This makes the interpretation of stream chemical parameters by PCA alone difficult unless complemented by other analyses such as end member mixing analysis. While, this study presents a preliminary attempt in understanding the long-term patterns and interactions of atmospheric deposition chemistry, climate variability and stream water chemistry from available long-term series in the Krycklan study catchment, possible future work would include end member mixing analysis in the catchment coupled with the application of ensembles of process based models to further understand the present dynamics and/or project possible future conditions of the catchment. Our expectation is that these will complement some other studies on metal biogeochemistry in the catchment (e.g. Lidman et al., 2011; Klaminder et al., 2011b) so as to quantify and/or constraint the uncertainties that can be associated with future projections under plausible climate change and forest management scenarios in the Krycklan study catchment.

Acknowledgements. We thank Ida Taberman for managing the Krycklan water quality database and others that have helped out in the field and in the laboratory. This study could not have been carried out without the Svartberget/Krycklan data collection that over the years have been funded by Swedish Science Council, Formas, SKB, Kempe Koundation, Mistra, VR and SLU. This project is part of two larger forest water programs, ForWater and Future Forests, studying the effect of climate and forest managements on forest water quality. We thank James Shanley and an anonymous reviewer for their comments which greatly improved the quality of the final manuscript.

Edited by: B. A. Bergamaschi

\section{References}

Ågren, A., Buffam, I., Berggren, M., Bishop, K., Jansson, M., and Laudon, H.: Dissolved organic carbon characteristics in boreal streams in a forest-wetland gradient during the transition between winter and summer, J. Geophys. Res.-Biogeo., 113, G03031, doi:10.1029/2007JG000674, 2008.

Ågren, A., Haei, M., Köhler, S. J., Bishop, K., and Laudon, H.: Regulation of stream water dissolved organic carbon (DOC) concentrations during snowmelt; the role of discharge, winter climate and memory effects, Biogeosciences, 7, 2901-2913, doi:10.5194/bg-7-2901-2010, 2010.

Aitkenhead-Peterson, J. A., Steele, M. K., Nahar, N., and Santhy, K.: Dissolved organic carbon and nitrogen in urban watersheds of south-central Texas: land use and land management influences, Biogeochemistry, 96, 119-129, doi:10.1007/s10533-009-93482, 2009.

Berggren, M., Laudon, H., and Jansson, M.: Landscape regulation of bacterial growth efficiency in boreal freshwaters, Global Biogeochem. Cy., 21, GB4002, doi:10.1029/2006GB002844, 2007.

Berggren, M., Laudon, H., and Jansson, M.: Hydrological control of organic carbon support for bacterial growth in boreal headwater streams, Microb. Ecol., 57, 170-178, 2009.

Bergknut, M., Laudon, H., Jansson, S., Larsson, A., Gocht, T., and Wiberg, K.: Atmospheric deposition, retention, and stream export of dioxins and PCBs in a pristine boreal catchment, Environ. Pollut., 159, 1592-1598, doi:10.1016/j.envpol.2011.02.050, 2011.

Bishop, K. and Pettersson, C.: Organic carbon in the boreal spring flood from adjacent subcatchments, Environ. Int., 22, 535-540, doi:10.1016/0160-4120(96)00036-0, 1996.

Bishop, K., Grip, H., and O'Neill, A.: The origins of acid runoff in a hillslope during storm events, J. Hydrol., 116, 35-61, doi:10.1016/0022-1694(90)90114-D, 1990.

Bishop, K., Lundström, U., and Giesler, R.: Transfer of organic$\mathrm{C}$ from forest soils to surface waters - example from Northern Sweden, Appl. Geochem., 11-15, 1993.

Bishop, K. H., Pettersson, C., Allard, B., and Lee, Y. H.: Identification of the riparian sources of aquatic DOC, Environ. Int., 20, 11-19, 1994.

Bishop, K., Lee, Y., Pettersson, C., and Allard, B.: Terrestrial sources of methylmercury in surface waters - the importance of the Riparian Zone on the Svartberget Catchment, Water Air Soil Poll., 80, 435-444, doi:10.1007/BF01189693, 1995.

Bishop, K., Laudon, H., and Köhler, S.: Separating the natural and anthropogenic components of spring flood $\mathrm{pH}$ decline: a method for areas that are not chronically acidified, Water Resour. Res., 36, 1873-1884, doi:1029/2000WR900030, 2000.

Bishop, K., Seibert, J., Köhler, S., and Laudon, H.: Resolving the double paradox of rapidly mobilized old water with highly variable responses in runoff chemistry, Hydrol. Process., 18, 185189, doi:1002/hyp.5209, 2004.

Bishop, K., Buffam, I., Erlandsson, M., Fölster, J., Laudon, H., Seibert, J., and Temnerud, J.: Aqua incognita: the unknown head- 
waters, Hydrol. Process., 22, 1239-1242, doi:1002/hyp.7049, 2008.

Blomberg, M.: Can a high-resolution digital elevation model predict the thickness of the organic soil layer in the riparian soil?, MSc Thesis, Swedish University of Agricultural Sciences, Uppsala, Sweden, 54 pp., 2009.

Brooks, M. L., Meyer, J. S., and McKnight, D. M.: Photooxidation of wetland and riverine dissolved organic matter: altered copper complexation and organic composition, Hydrobiologia, 579, 95113, 2007.

Buffam, I., Laudon, H., Temnerud, J., Mörth, C., and Bishop, K.: Landscape-scale variability of acidity and dissolved organic carbon during spring flood in a boreal stream network RID H-4458-2011, J. Geophys. Res.-Biogeo., 112, G01022, doi:10.1029/2006JG000218, 2007.

Buffam, I., Laudon, H., Seibert, J., Morth, C., and Bishop, K.: Spatial heterogeneity of the spring flood acid pulse in a boreal stream network, Sci. Total Environ., 407, 708-722, doi:10.1016/j.scitotenv.2008.10.006, 2008.

Clark, J. M., Bottrell, S. H., Evans, C. D., Monteith, D. T., Bartlett, R., Rose, R., Newton, R. J., and Chapman, P. J.: The importance of the relationship between scale and process in understanding long-term DOC dynamics, Sci. Total Environ., 408, 2768-2775, 2010.

Cory, N., Laudon, H., Köhler, S., Seibert, J., and Bishop, K.: Evolution of soil solution aluminum during transport along a forested boreal hillslope, J. Geophys. Res.-Biogeo., 112, G03014, doi:10.1029/2006JG000387, 2007.

Dawson, J. J. C., Malcolm, I. A., Middlemas, S. J., Tetzlaff, D., and Soulsby, C.: Is the composition of dissolved organic carbon changing in Upland Acidic streams?, Environ. Sci. Technol., 43, 7748-7753, 2009.

De Wit, H. A., Mulder, J., Hindar, A., and Hole, L.: Long-term increase in dissolved organic carbon in streamwaters in Norway is response to reduced acid deposition, Environ. Sci. Technol., 41, 7706-7713, 2007.

Eimers, M. C., Watmough, S. A., and Buttle, J. M.: Long-term trends in dissolved organic carbon concentration: a cautionary note, Biogeochemistry, 87, 71-81, 2008.

Eklöf, K., Fölster, J., Sonesten, L., and Bishop, K.: Spatial and temporal variation of $\mathrm{THg}$ concentrations in run-off water from 19 boreal catchments, 2000-2010, Environ. Pollut., 164, 102-109, 2012.

Erlandsson, M., Buffam, I., Fölster, J., Laudon, H., Temnerud, J., Weyhenmeyer, G. A., and Bishop, K.: Thirty-five years of synchrony in the organic matter concentrations of Swedish rivers explained by variation in flow and sulphate, Glob. Change Biol., 14, 1191-1198, 2008.

Esseen, P. A., Ehnstrom, B., Ericson, L., and Sjöblom, K.: Boreal forests, Ecol. Bull., 46, 16-47, 1997.

Evans, C. D., Monteith, D. T., and Cooper, D. M.: Long-term increases in surface water dissolved organic carbon: observations, possible causes and environmental impacts, Environ. Pollut., 137, 55-71, 2005.

Evans, C. D., Chapman, P. J., Clark, J. M., Monteith, D. T., and Cresser, M. S.: Alternative explanations for rising dissolved organic carbon export from organic soils, Glob. Change Biol., 12, 2044-2053, 2006.
Fenner, N., Freeman, C., Lock, M. A., Harmens, H., Reynolds, B., and Sparks, T.: Interactions between elevated $\mathrm{CO}_{2}$ and warming could amplify DOC exports from peatland catchments, Environ. Sci. Technol., 41, 3146-3152, 2007.

Findlay, S.: Increased carbon transport in the Hudson River: unexpected consequence of nitrogen deposition?, Front. Ecol. Environ., 3, 133-137, 2005.

Fölster, J., Andren, C., Bishop, K., Buffam, I., Cory, N., Goedkoop, W., Holmgren, K., Johnsson, R., Laudon, H., and Wilander, A.: A novel environmental quality criterion for acidification in Swedish Lakes - An application of studies on the relationship between biota and water chemistry, Water Air Soil Poll., Focus, 7, 331338, doi:1067/s11267-006-9075-9, 2007.

Freeman, C., Fenner, N., Ostle, N. J., Kang, H., Dowrick, D. J., Reynolds, B., Lock, M. A., Sleep, D., Hughes, S., and Hudson, J.: Export of dissolved organic carbon from peatlands under elevated carbon dioxide levels, Nature, 430, 195-198, 2004.

Futter, M. N., Butterfield, D., Cosby, B. J., Dillon, P. J., Wade, A. J., and Whitehead, P. G.: Modeling the mechanisms that control in-stream dissolved organic carbon dynamics in upland and forested catchments, Water Resour. Res., 43, W02424, doi:10.1029/2006WR004960, 2007.

Futter, M. N., Forsius, M., Holmberg, M., and Starr, M.: Modelling the impact of European emission and climate change scenarios on dissolved organic carbon concentrations the surface waters of a boreal catchment, Hydrol. Res., 40, 291-305, 2009.

Futter, M. N., Löfgren, S., Köhler, S. J., Lundin, L., Moldan, F., and Bringmark, L.: Simulating dissolved organic carbon dynamics at the Swedish integrated monitoring sites with the integrated catchments model for carbon, INCA-C, Ambio, 40, 906-919, 2011.

Galloway, J. N., Norton, S. A., and Church, M. R.: Freshwater acidification from atmospheric deposition of sulfuric acids: a conceptual model, Environ. Sci. Technol., 17, 541-545, 1983.

Grabs, T., Bishop, K., Laudon, H., Lyon, S. W., and Seibert, J.: Riparian zone hydrology and soil water total organic carbon (TOC): implications for spatial variability and upscaling of lateral riparian TOC exports, Biogeosciences, 9, 3901-3916, doi:10.5194/bg-9-3901-2012, 2012.

Grip, H. and Bishop, K. H.: Chemical dynamics of an acid stream rich in dissolved organics, in: The Surface Water Acidification Programme, edited by: Mason, B. J., Royal Society, London, 7584, 1990.

Hernandez, D., Plaza, C., Senesi, N., and Polo, A.: Detection of copper(II) and zinc(II) binding to humic acids from pig slurry and amended soils by fluorescence spectroscopy, Environ. Pollut., 143, 212-220, doi:10.1016/j.envpol.2005.11.038, 2006.

Hongve, D., Riise, G., and Kristiansen, J. F.: Increased colour and organic acid concentrations in Norwegian forest lakes and drinking water - a result of increased precipitation?, Aquat. Sci., 66, 231-238, 2004.

Huser, B. J., Köhler, S. J., Wilander, A., Johansson, K., and Fölster, J.: Temporal and spatial trends for trace metals in streams and rivers across Sweden (1996-2009), Biogeosciences, 8, 18131823, doi:10.5194/bg-8-1813-2011, 2011.

Huser, B. J., Fölster, J., and Köhler, S. J.: Lead, zinc, and chromium concentrations in acidic headwater streams in Sweden explained by chemical, climatic, and land-use variations, Biogeosciences, 9, 4323-4335, doi:10.5194/bg-9-4323-2012, 2012. 
Jansen, B., Nierop, K., and Verstraten, J.: Mechanisms controlling the mobility of dissolved organic matter, aluminium and iron in podzol B horizons, Eur. J. Soil Sci., 56, 537-550, doi:10.1111/j.1365-2389.2004.00686.x, 2005.

Kalbitz, K., Solinger, S., Park, J. H., Michalzik, B., and Matzner, E.: Controls on the dynamics of dissolved organic matter in soils: a review, Soil Sci., 165, 277-304, 2000.

Kerr, J. G. and Eimers, M. C.: Decreasing soil water $\mathrm{Ca}^{2+}$ reduces DOC adsorption in mineral soils: implications for long-term DOC trends in an upland forested catchment in Southern Ontario, Canada, Sci. Total Environ., 427, 298-307, doi:10.1016/j.scitotenv.2012.04.016, 2012.

Klaminder, J., Bindler, R., Laudon, H., Bishop, K., Emteryd, O., and Renberg, I.: Flux rates of atmospheric lead pollution within soils of a small catchment in Northern Sweden and their implications for future stream water quality, Environ. Sci. Technol., 40, 46394645, 2006.

Klaminder, J., Grip, H., Mörth, C. M., and Laudon, H.: Carbon mineralization and pyrite oxidation in groundwater: importance for silicate weathering in boreal forest soils and stream base-flow chemistry, Appl. Geochem., 26, 319-324, doi:10.1016/j.apgeochem.2010.12.005, 2011a.

Klaminder, J., Lucas, R. W., Futter, M. N., Bishop, K. H., Köhler, S. J., Egnell, G., and Laudon, H.: Silicate mineral weathering rate estimates: are they precise enough to be useful when predicting the recovery of nutrient pools after harvesting?, Forest Ecol. Manag., 261, 1-9, doi:10.1016/j.foreco.2010.09.040, 2011 b.

Köhler, S., Buffam, I., Jonsson, A., and Bishop, K.: Photochemical and microbial processing of stream and soilwater dissolved organic matter in a boreal forested catchment in Northern Sweden, Aquat. Sci., 64, 269-281, doi:10.1007/s00027-002-8071-z, 2002.

Köhler, S. J., Buffam, I., Laudon, H., and Bishop, K. H.: Climate's control of intra-annual and interannual variability of total organic carbon concentration and flux in two contrasting boreal landscape elements, J. Geophys. Res.-Biogeo., 113, G03012, doi:10.1029/2007JG000629, 2008.

Köhler, S. J., Buffam, I., Seibert, J., Bishop, K. H., and Laudon, H.: Dynamics of stream water TOC concentrations in a boreal headwater catchment: controlling factors and implications for climate scenarios, J. Hydrol., 373, 44-56, 2009.

Kothawala, D. N., Moore, T. R., and Hendershot, W. H.: Soil properties controlling the adsorption of dissolved organic carbon to mineral soils, Soil Sci. Soc. Am. J., 1831-1842, 2009.

Landre, A. L., Watmough, S. A., and Dillon, P. J.: The effects of dissolved organic carbon, acidity and seasonality on metal geochemistry within a forested catchment on the precambrian shield, Central Ontario, Canada, Biogeochemistry, 93, 271-289, 2009.

Laudon, H. and Bishop, K.: The rapid and extensive recovery from episodic acidification in Northern Sweden due to declines in $\mathrm{SO}_{4}^{2-}$ deposition, Geophys. Res. Lett., 29, 1594, doi:10.1029/2001GL014211, 2002.

Laudon, H. and Hemond, H.: Recovery of streams from episodic acidification in Northern Sweden, Environ. Sci. Technol., 36, 921-928, doi:10.1021/es0110473, 2002.

Laudon, H., Köhler, S., and Bishop, K.: Natural acidity or anthropogenic acidification in the spring flood of Northern Sweden?, Sci. Total Environ., 234, 63-73, doi:10.1016/S00489697(99)00259-4, 1999.
Laudon, H., Köhler, S., and Buffam, I.: Seasonal TOC export from seven boreal catchments in Northern Sweden, Aquat. Sci., 66, 223-230, 2004a.

Laudon, H., Seibert, J., Köhler, S., and Bishop, K.: Hydrological flow paths during snowmelt: congruence between hydrometric measurements and oxygen 18 in meltwater, soil water, and runoff, Water Resour. Res., 40, W03102, doi:10.1029/2003WR002455, 2004b.

Laudon, H., Sjoblom, V., Buffam, I., Seibert, J., and Mörth, M.: The role of catchment scale and landscape characteristics for runoff generation of boreal streams, J. Hydrol., 344, 198-209, 2007.

Laudon, H., Berggren, M., Ågren, A., Buffam, I., Bishop, K., Grabs, T., Jansson, M., and Kohler, S.: Patterns and dynamics of dissolved organic carbon (DOC) in boreal streams: the role of processes, connectivity, and scaling, Ecosystems, 14, 880-893, 2011.

Laudon, H., Buttle, J., Carey, S. K., McDonnell, J., McGuire, K., Seibert, J., Shanley, J., Soulsby, C., and Tetzlaff, D.: Crossregional prediction of long-term trajectory of stream water DOC response to climate change, Geophys. Res. Lett., 39, L18404, doi:10.1029/2012GL053033, 2012.

Lepistö, A., Kortelainen, P., and Mattsson, T.: Increased organic C and $\mathrm{N}$ leaching in a northern boreal river basin in Finland, Global Biogeochem. Cy., 22, GB3029, doi:10.1029/2007GB003175, 2008.

Libiseller, C. and Grimvall, A.: Performance of partial MannKendall tests for trend detection in the presence of covariates, Environmetrics, 13, 71-84, doi:10.1002/env.507, 2002.

Lidman, F., Mörth, C., Bjorkvald, L., and Laudon, H.: Selenium dynamics in boreal streams: the role of wetlands and changing groundwater tables, Environ. Sci. Technol., 45, 2677-2683, doi:10.1021/es102885z, 2011.

Löfvenius, M., Kluge, M., and Lundmark, T.: Snow and soil frost depth in two types of shelterwood and a clear-cut area, Scand. J. Forest Res., 18, 54-63, doi:1038313810.1080/02827581.2003, 2003.

Lyon, S. W., Grabs, T., Laudon, H., Bishop, K. H., and Seibert, J.: Variability of groundwater levels and total organic carbon in the riparian zone of a boreal catchment, J. Geophys. Res.-Biogeo., 116, G01020, doi:10.1029/2010JG001452, 2011.

McGlynn, B. L. and McDonnell, J. J.: Role of discrete landscape units in controlling catchment dissolved organic carbon dynamics, Water Resour. Res., 39, 1090, doi:10.1029/2002WR001525, 2003.

Monteith, D. T., Stoddard, J. L., Evans, C. D., de Wit, H. A., Forsius, M., Hogasen, T., Wilander, A., Skjelkvale, B. L., Jeffries, D. S., Vuorenmaa, J., Keller, B., Kopacek, J., and Vesely, J.: Dissolved organic carbon trends resulting from changes in atmospheric deposition chemistry, Nature, 450, 537-540, doi:10.1038/nature06316, 2007.

Munch, J., Totsche, K., and Kaiser, K.: Physicochemical factors controlling the release of dissolved organic carbon from columns of forest subsoils, Eur. J. Soil Sci., 53, 311-320, doi:10.1046/j.1365-2389.2002.00439.x, 2002.

Oni, S. K., Futter, M. N., and Dillon, P. J.: Landscape-scale control of carbon budget of Lake Simcoe: a process-based modelling approach, J. Great Lakes Res., 37, 160-165, 2011.

Oni, S. K., Futter, M. N., Molot, L. A., and Dillon, P. J.: Modelling the long term impact of climate change on the carbon budget of 
Lake Simcoe, Ontario using INCA-C, Sci. Total Environ., 414, 387-403, 2012.

Oni, S. K., Futter, M. N., Molot, L. A., and Dillon, P. J.: Adjacent catchments with similar patterns of land use and climate have markedly different DOC and runoff dynamics, Hydrol. Process., doi::10.1002/hyp.9681, 2013.

Preston, M. D., Eimers, M. C., and Watmough, S. A.: Effect of moisture and temperature variation on DOC release from a peatland: Conflicting results from laboratory, field and historical data analysis, Sci. Total Environ., 409, 1235-1242, doi:10.1016/j.scitotenv.2010.12.027, 2011.

Raulund-Rasmussen, K., Borggaard, O. K., Hansen, H. C. B., and Olsson, M.: Effect of natural organic soil solutes on weathering rates of soil minerals, Eur. J. Soil Sci., 49, 397-406, 1998.

Ravichandran, M.: Interactions between mercury and dissolved organic matter - a review, Chemosphere, 55, 319-331, 2004.

Salmi, T., Määttä, A., Anttila, P., Ruoho-Airola, T., and Amnell, T.: Detecting trends of annual values of atmospheric pollutants by the Mann-Kendall test and Sen's slope estimates MAKESENS The excel template application, Finish Meteorological Institute, Helsinki, 35 pp., 2002.

Schelker, J., Eklöf, K., Bishop, K., and Laudon, H.: Effects of forestry operations on dissolved organic carbon concentrations and export in boreal first-order streams, J. Geophys. Res.Biogeo., 117, G01011, doi:10.1029/2011JG001827, 2012.

Schindler, D. W., Curtis, P. J., Bayley, S. E., Parker, B. R., Beaty, K. G., and Stainton, M. P.: Climate-induced changes in the dissolved organic carbon budgets of boreal lakes, Biogeochemistry, 36, 928, 1997.

Seibert, J., Grabs, T., Köhler, S., Laudon, H., Winterdahl, M., and Bishop, K.: Linking soil- and stream-water chemistry based on a Riparian Flow-Concentration Integration Model, Hydrol. Earth Syst. Sci., 13, 2287-2297, doi:10.5194/hess-13-22872009, 2009.

Selberg, A., Viik, M., Ehapalu, K., and Tenno, T.: Content and composition of natural organic matter in water of Lake Pitkjarv and mire feeding Kuke River (Estonia), J. Hydrol., 400, 274-280, 2011.

SEPA: Status, potential and quality requirements for lakes, watercourses, coastal and transitional waters, Swedish Environmental protection Agency, Stockholm, Sweden, 421 pp., 2007.

Shank, G. C., Skrabal, S. A., Whitehead, R. F., and Kieber, R. J.: Strong copper complexation in an organic-rich estuary: the importance of allochthonous dissolved organic matter, Mar. Chem., 88, 21-39, 2004.

Striegl, R., Aiken, G., Dornblaser, M., Raymond, P., and Wickland, K.: A decrease in discharge-normalized DOC export by the Yukon River during summer through autumn, Geophys. Res. Lett., 32, L21413, doi:10.1029/2005GL024413, 2005.

Tegen, I. and Dorr, H.: Mobilization of cesium in organic rich soils: correlation with production of dissolved organic carbon, Water Air Soil Poll., 88, 133-144, 1996.

Temnerud, J. and Bishop, K.: Spatial variation of streamwater chemistry in two Swedish boreal catchments: implications for environmental assessment, Environ. Sci. Technol., 39, 14631469, doi:10.1021/es040045q, 2005.
Temnerud, J., Fölster, J., Buffam, I., Laudon, H., Erlandsson, M., and Bishop, K.: Can the distribution of headwater stream chemistry be predicted from downstream observations?, Hydrol. Process., 24, 2269-2276, doi:10.1002/hyp.7615, 2010.

Thiffault, E., Hannam, K. D., Pare, D., Titus, B. D., Hazlett, P. W., Maynard, D. G., and Brais, S.: Effects of forest biomass harvesting on soil productivity in boreal and temperate forests - a review, Environ. Rev., 19, 278-309, doi:10.1139/A11-009, 2011.

Vermohlen, K., Lewandowski, H., Narres, H., and Schwuger, M.: Adsorption of polyelectrolytes onto oxides - the influence of ionic strength, molar mass, and $\mathrm{Ca}^{2+}$ ions, Colloids Surface. A, 163, 45-53, doi:10.1016/S0927-7757(99)00429-X, 2000.

Watmough, S. and Dillon, P.: Base cation losses from a coniferous catchment in Central Ontario, Canada, Water Air Soil Poll., 507524, 2001.

Watmough, S. and Dillon, P.: Base cation and nitrogen budgets for a mixed hardwood catchment in South-Central Ontario, Ecosystems, 6, 675-693, doi:10.1007/s10021-002-0164-y, 2003.

Watmough, S., Aherne, J., Alewell, C., Arp, P., Bailey, S., Clair, T., Dillon, P., Duchesne, L., Eimers, C., Fernandez, I., Foster, N., Larssen, T., Miller, E., Mitchell, M., and Page, S.: Sulphate, nitrogen and base cation budgets at 21 forested catchments in Canada, the United States and Europe, Environ. Monit. Assess., 109, 1-36, doi:10.1007/s10661-005-4336-z, 2005.

Winterdahl, M., Futter, M., Köhler, S., Laudon, H., Seibert, J., and Bishop, K.: Riparian soil temperature modification of the relationship between flow and dissolved organic carbon concentration in a boreal stream, Water Resour. Res., 47, W08532, doi:10.1029/2010WR010235, 2011a.

Winterdahl, M., Temnerud, J., Futter, M., Löfgren, S., Moldan F., and Bishop, K.: Riparian zone influence on stream water total organic carbon concentrations at the Swedish Integrated Monitoring sites, Ambio, 40, 920-930, 2011 b.

Worrall, F. and Burt, T.: Predicting the future DOC flux from upland peat catchments, J. Hydrol., 300, 126-139, doi:10.1016/j.jhydrol.2004.06.007, 2005.

Worrall, F., Harriman, R., Evans, C. D., Watts, C. D., Adamson, J., Neal, C., Tipping, E., Burt, T., Grieve, I., and Monteith, D.: Trends in dissolved organic carbon in UK rivers and lakes, Biogeochemistry, 70, 369-402, 2004.

Yue, S., Pilon, P., and Cavadias, G.: Power of the Mann-Kendall and Spearman's rho tests for detecting monotonic trends in hydrological series, J. Hydrol., 259, 254-271, doi:10.1016/S00221694(01)00594-7, 2002.

Yurova, A., Sirin, A., Buffam, I., Bishop, K., and Laudon, H.: Modeling the dissolved organic carbon output from a boreal mire using the convection-dispersion equation: importance of representing sorption, Water Resour. Res., 44, W07411, doi:10.1029/2007WR006523, 2008. 